Article

\title{
New Data and Evidence on the Mineralogy and Geochemistry of Wulantuga High-Ge Coal Deposit of Shengli Coalfield, Inner Mongolia, China
}

\author{
Chen Yao ${ }^{1}$, Xinguo Zhuang ${ }^{1, *}$, Xavier Querol ${ }^{1,2}{ }^{2} \operatorname{Jing~Li}^{1}$, Baoqing $\mathrm{Li}^{1}{ }^{1}$, Natalia Moreno ${ }^{2} \mathbb{D}$ and \\ Feng Zhang ${ }^{1}$ \\ 1 Key Laboratory of Tectonics and Petroleum Resources, China University of Geosciences, Ministry of \\ Education, Wuhan 430074, China; eric_yao@cug.edu.cn (C.Y.); xavier.querol@idaea.csic.es (X.Q.); \\ lijing02003140@163.com (J.L.); libq@cug.edu.cn (B.L.); zf140602@126.com (F.Z.) \\ 2 Institute of Environmental Assessment and Water Research, CSIC, C/LLuis Solé Sabarís s/n, 08028 Barcelona, \\ Spain; natalia.moreno@idaea.csic.es \\ * Correspondence: xgzhuang@cug.edu.cn
}

Received: 8 November 2019; Accepted: 19 December 2019; Published: 24 December 2019

\begin{abstract}
The mode of occurrence and origin of highly-enriched trace elements, especially Ge, in Wulantuga high-Ge coal deposit have been widely reported. In this study, coal samples and several coalified trunks embedded within the roof strata are collected, which provides a good opportunity to further confirm if Ge is mainly associated with organic matter. Minerals in coal samples are mainly quartz, kaolinite, montmorillonite, pyrite, and gypsum, along with trace albite, barite, chlorite, and Fe-oxide, while those in coalified trunk samples include melanterite, pyrite, and gypsum, with traces of chlorite and magnesiocopiapite. Germanium, $\mathrm{As}, \mathrm{W}, \mathrm{Sb}, \mathrm{Hg}, \mathrm{Be}$, and $\mathrm{Cs}$ are enriched in coal samples, and these elements are also enriched in the coalified trunks and roof glutenite. The elevated contents of $\mathrm{Ge}, \mathrm{As}, \mathrm{W}, \mathrm{Sb}$, and $\mathrm{Hg}$ were almost exclusively derived from the influx of hydrothermal fluids as evidenced by the presence of pyrite veins and chamosite as well as enhanced elemental associations of Ge-W and As-Sb-Hg in the studied lignite samples. The coalified trunks in the study area should be taken into consideration due to the high contents of hazardous elements that cause potential environmental impacts during mining waste disposal and land reclamation.
\end{abstract}

Keywords: China; Germanium; coal; Wulantuga; coalified trunk

\section{Introduction}

Critical elements, including rare earth elements, in coal have attracted significant attention in recent years due to their increasing prevalence in industrial technologies and their contributions to the economy [1]. Previous studies have found a number of coals being considered as an economic source of scores of critical elements, including $\mathrm{Ge}, \mathrm{Ga}, \mathrm{U}, \mathrm{V}$, Se, rare earth elements and $\mathrm{Y}$ (REY or REE if $\mathrm{Y}$ is not included), Sc, Y, Nb, Au, Ag, platinum group elements (PGEs), and Re, as well as some base metals, such as $\mathrm{Al}$ and $\mathrm{Mg}$ [1-6]. Further, there are cases where the industrial utilization of critical elements from coal has been successful, such as for $\mathrm{Ga}, \mathrm{Ge}, \mathrm{Se}, \mathrm{U}$, and V. Other critical elements, including $\mathrm{Nb}$, $\mathrm{Au}, \mathrm{Ag}, \mathrm{Re}, \mathrm{Al}, \mathrm{Mg}$, and REY, are considered to have prospects for the recovery from coal deposits [1].

Among the above-mentioned critical elements, Ge has been studied intensively for its high economic value in novel, highly technological industrial applications and the discovery of the unusual enrichment of Ge in coals [6-18]. Zilbermints et al. [19] first reported Ge enrichment in coal. Subsequently, Hu et al. [20], Wang [21], Seredin et al. [16,22,23], Wu et al. [24], and Hower et al. [11] investigated the occurrence and distribution of Ge in Lincang (Yunnan, China), Wulantuga (Inner 
Mongolia, China), Russian Far East, Yimin (Inner Mongolia, China) and Western Kentucky coalfield (United States of America). Kulinenko [25] evaluated the association between Ge content and thickness of coal seams and found an inverse relationship between germanium content and seam thickness. Yudovich [26] noticed a marginal enrichment of Ge in coal beds. Hu et al. [20,27], Zhuang et al. [28], Qi and Hu [29], Qi et al. [30], Li et al. [31], Dai et al. [8], Wei and Rimmer [32], Wei et al. [33] reported on the geological settings, major patterns of the coal-bearing strata, coal quality, geochemistry and mineralogy, and modes of Ge occurrence, as well as the origin of Ge enrichment, in the Lincang coal deposit in Bangmai coalfield. Du et al. [10,34], Zhuang et al. [18], Qi et al. [15,35], Li et al. [31], Dai et al. [7,9], Wei and Rimmer [32], and Wei et al. [33] carried out similar investigations on the Wulantuga coal deposit in Shengli coalfield. Dai et al. [36] confirmed an exclusive organic affinity for Ge in coal.

The above studies on the Cretaceous Wulantuga coal deposit reported very high concentrations of Ge, exceeding $1500 \mathrm{mg} / \mathrm{kg}$ in some of the samples [7,9,10,15,18,31-35]. These studies also reported co-enrichments in a number of elements, such as W, As, Sb, Hg, F, Be, Cs, Tl, Au, Ag, and PGEs, among others. These enrichments were mostly attributed to hydrothermal solutions affecting coal deposits.

With the process of mineral exploitation, the mining area of the Wulantuga open-pit mine has been expanded northward. In previous studies about coals from Wulantuga, both high-Ge and low-Ge, were sampled in the original area of the Wulantuga coal deposit $[7,9,10,15,18,31-35,37]$. Now that the mining area has been expanded, it is necessary to investigate the property of coals in the new mining area. During geological surveys of the Wulantuga high-Ge coal deposit, we discovered large amounts of coalified trunks embedded within the roof glutenite of a high-Ge coal seam, which provides a good opportunity to further confirm if Ge is mainly associated with organic matter. In this paper, we report the mineralogical and geochemical data of coal and coalified trunks in the new mining area and put emphasis on the mode of occurrence, lateral distribution, and enrichment mechanism of Ge. Alternatively, the potential for resource recovery and environmental impact of coalified trunks are also be discussed.

\section{Geological Setting}

The Shengli Coalfield was deposited in the fault-controlled Shengli sub-basin of the Erlian Basins in northeastern Inner Mongolia [38,39], which is $45 \mathrm{~km}$ long and $7.6 \mathrm{~km}$ wide, with a total area of $342 \mathrm{~km}^{2}$ (Figure 1). The Wulantuga Ge-coal deposit only covers an area of $2.2 \mathrm{~km}^{2}$ within a southwestern margin of the coalfield, as outlined by the Coal Geology Bureau of Inner Mongolia following two periods of geologic exploration in 1998 and 2005 (Figure 2) [10]. 
A

B

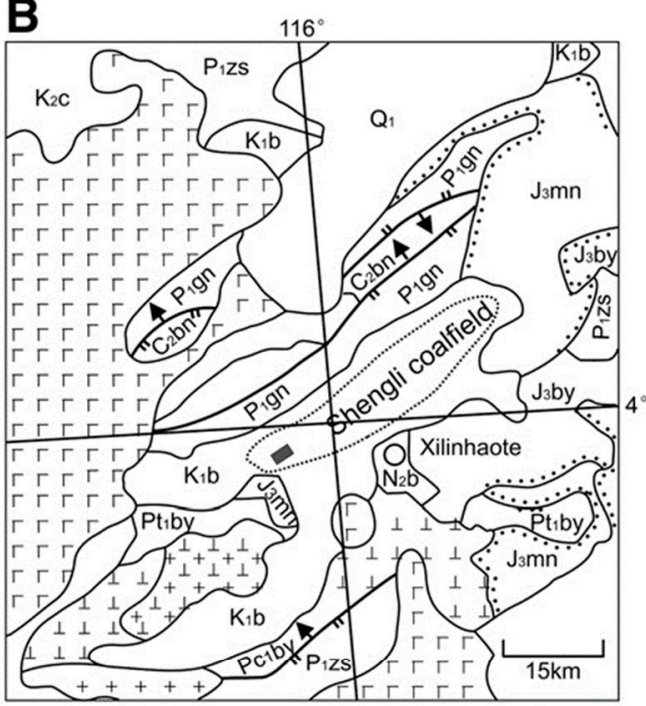

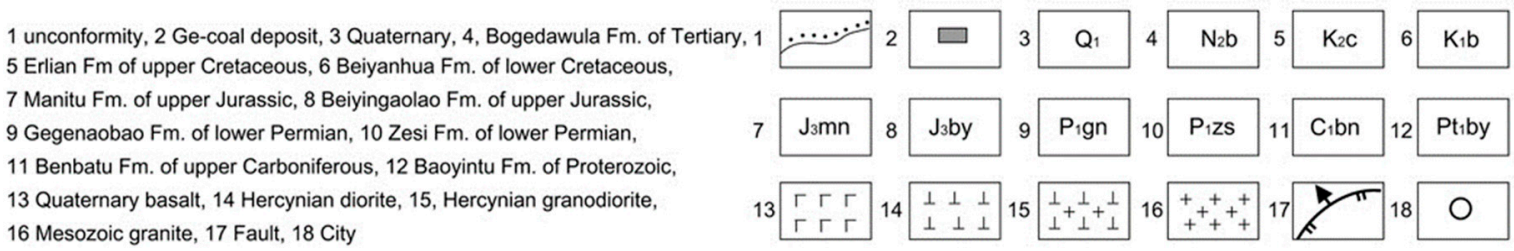

Figure 1. Geological setting of the Wulantuga high-Ge coal deposit [10,21]. (A): Location of the Ge ore deposits in China; (B): geological setting of the Wulantuga Ge ore deposit.

The sedimentary sequences in the Wulantuga high-Ge coal deposit include Silurian, Devonian, Permian, Late Jurassic, Early Cretaceous, Neogene, and Quaternary strata (Figure 2), and detailed information of these strata has been described by previous studies such as Dai et al. [9], Du et al. [10], Sha [40], and Li et al. [31].

Tectonically, the high-Ge coal deposit is located within a monocline structure with an NW dip and is limited by normal faults on the $\mathrm{N}$ and $\mathrm{S}$ boundaries [21]. The coal seams extend NW from the eroded SE outcrop of the deposit across an N-dipping structure. The structural conditions allow the Wulantuga deposit to be worked in open pits. The deposit is surrounded on the NW by Quaternary basalts, on the SW by Hercynian granodiorites, and on the SE by Hercynian diorites (Figure 1). 


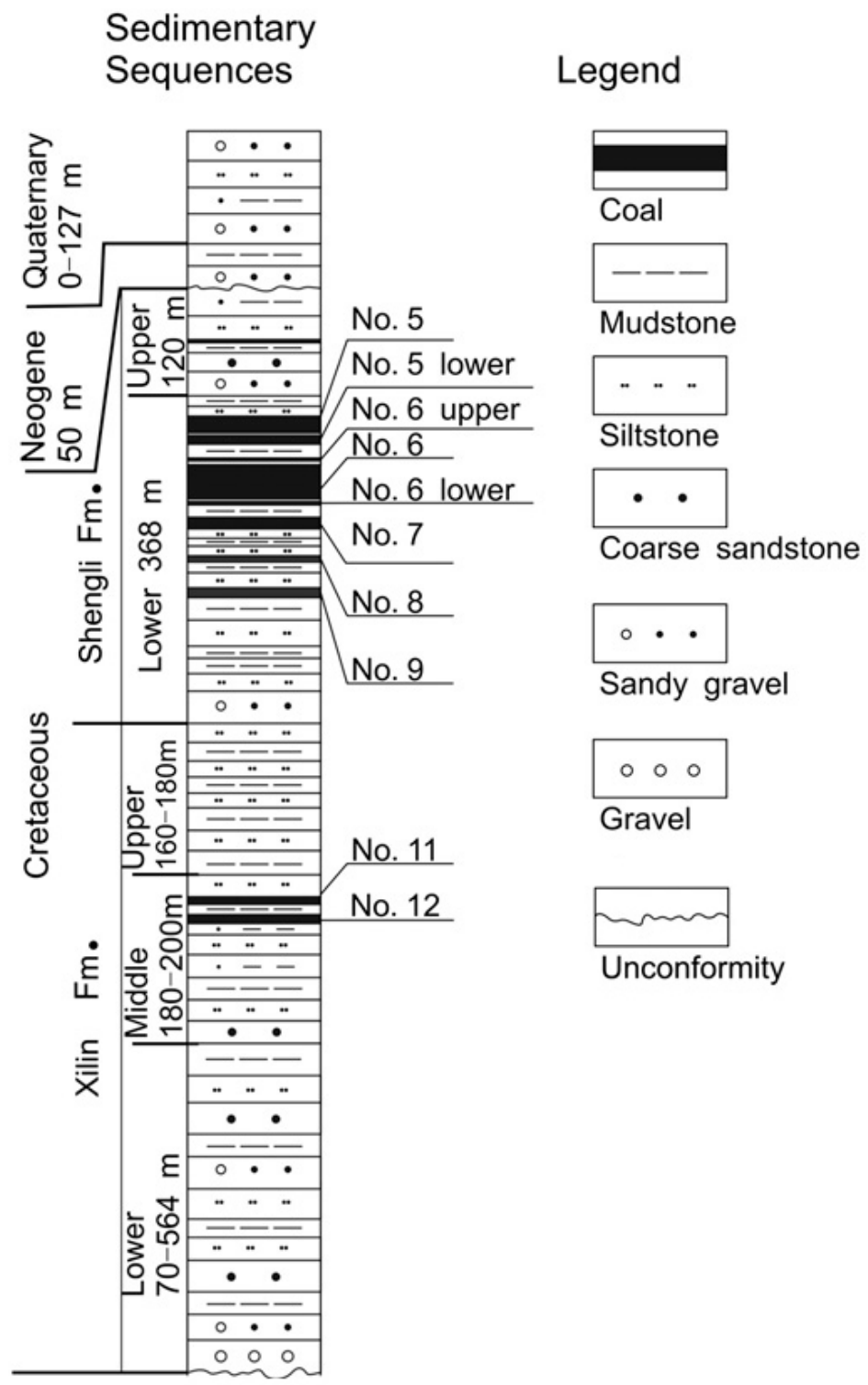

Figure 2. The sedimentary sequence of the High-Ge Wulantuga deposit [9].

\section{Methodology}

\subsection{Sampling}

A total of fourteen samples was collected from the high-Ge Wulantuga open-pit coal mine in the Shengli Coalfield (Figures 3 and 4), including nine coal bench samples from the section of \#6 coal (WZ-01 to WZ-09 from top to bottom), two glutenite samples from the roof of \#6 coal (WLTG-02 and WLTG-04), two coalified trunk samples from the roof of \#6 coal (WLTG-01 and WLTG-03), and a sample from mineralized infilling of a fracture of \#6 coal (WLTG-PY). Each coal bench sample (WZ-01 to WZ-09) cut was about 10-cm wide and 10-cm deep (Figure 4A). WLTG-03 was collected from the central part of the coalified trunk while WLTG-01 from the outer part of it (Figure 4B,D,F). WLTG-02 was collected from the roof glutenite and WLTG-04 from the area adjacent to the coalified trunk (Figure 4F). WLTG-PY was a pyrite sample collected from a fracture in the middle part of the No. 6 coal seam (Figure 4A,C,E). All collected samples were immediately stored in plastic bags to minimize contamination and oxidation. 


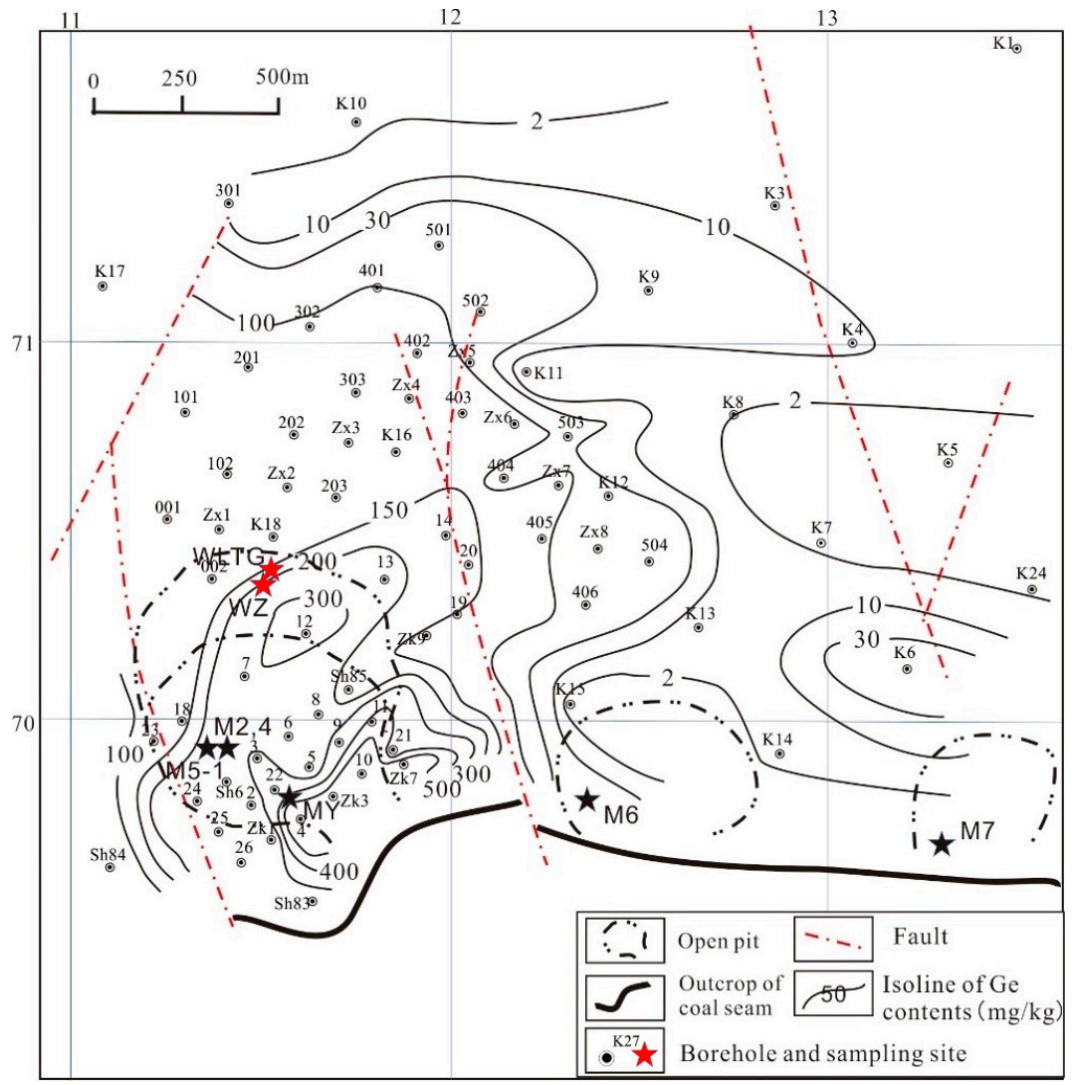

Figure 3. Sampling position of this study.
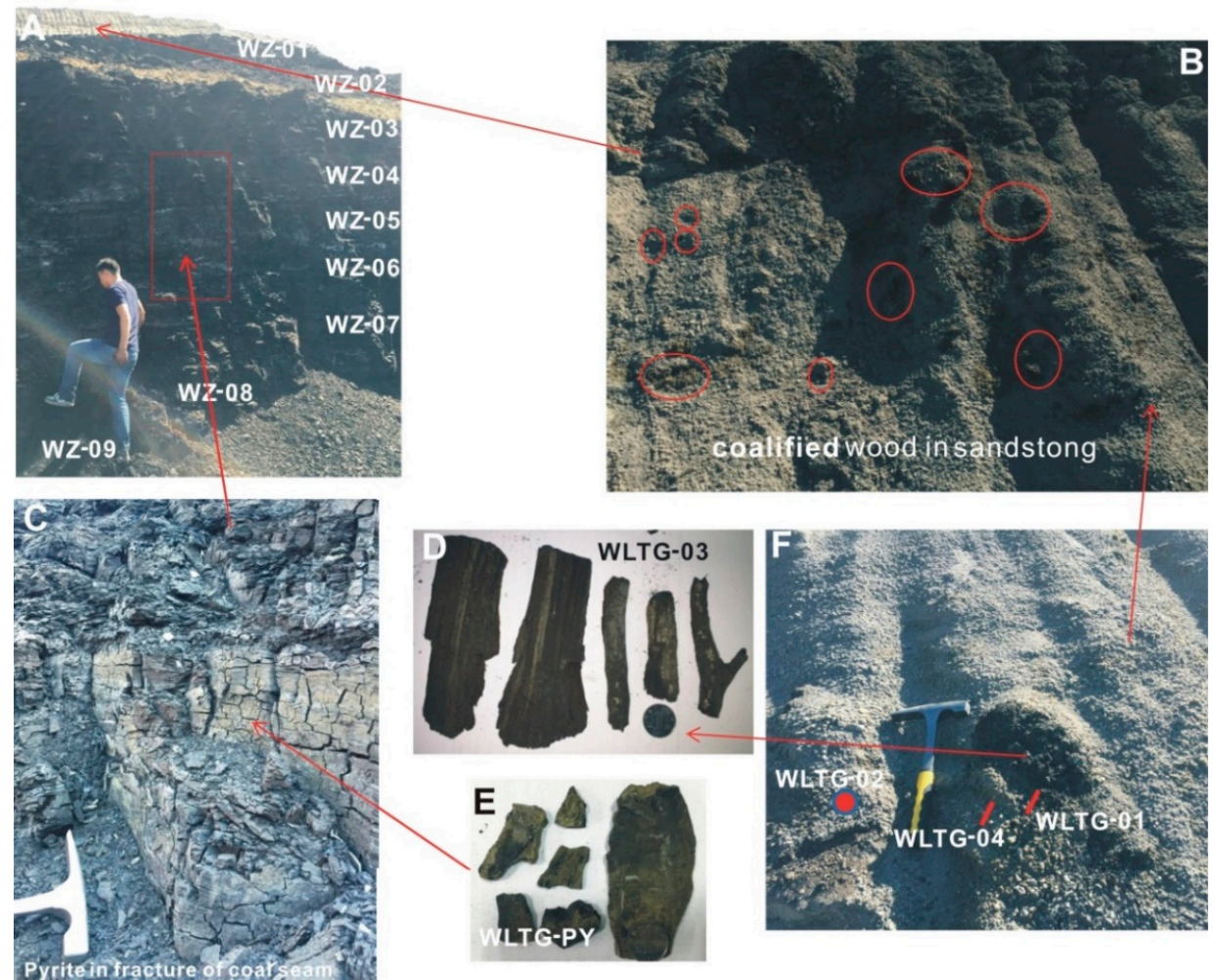

Figure 4. Samples collected from the Wulantuga open-pit mine. (A) The sampling location across the profile; (B) coalified woods in roof; (C) pyrite in fracture of coal seam; (D) coalified wood samples; (E) pyrite veins; (F) sampling location of coalified wood and roof glutenite samples. 
Subsequently, the samples were first crushed and ground to pass $1 \mathrm{~mm}$ sieve and then homogenized for maceral analysis. Then, the samples were crushed to powder samples (passing a 200-mesh sieve) for proximate analysis, geochemical, and mineralogical analyses. The powder coal with size $<1 \mathrm{~mm}$ was prepared and polished for the SEM-EDX analysis.

\subsection{Analytical Procedures}

Proximate analyses were performed following the ISO 589 [41], ISO 1171 [42], and ISO 562 [43] recommendations.

Maceral analyses were carried out in accordance with the classification of the International Committee for Coal and Organic Petrology (ICCP System 1994) [44-46] using conventional reflected-light, oil-immersion microscopy.

Mineral compositions of all samples were determined by means of powder X-ray diffraction (XRD). The reference intensity method was used to obtain semi-quantitative XRD estimation of the mineral contents in the studied samples [47]. A field emission-scanning electron microscope (QUANTA 200), equipped with an energy-dispersive X-ray spectrometer (EDX), was used to identify the morphology and modes of occurrence of minerals.

For major and trace element concentrations, a two-step acid-digestion method (first with $\mathrm{HNO}_{3}$ and secondly with mixtures of $\mathrm{HNO}_{3}, \mathrm{HF}$, and $\mathrm{HClO}_{4}$ ) was used prior to determination, in order to retain any volatile elements of the studied samples in solution [48]. The resulting solutions were analyzed by inductively coupled plasma atomic-emission spectrometry (ICP-AES) for major element concentrations, and by inductively coupled plasma mass spectrometry (ICP-MS) for trace element concentration.

It is worth noting that due to the formation of highly volatile $\mathrm{SiF}_{6}$ during the digestion process and the consequent $\mathrm{Si}$ loss, $\mathrm{Si}$ concentrations were calculated through a mass balance method, combining the mineralogical and geochemical data, using $\mathrm{Al}$ as a reference [49]. The calculated $\mathrm{Si}$ and $\mathrm{Al}$ concentrations were respectively estimated by counting up the $\mathrm{Si}$ and $\mathrm{Al}$ concentrations in all minerals detected by XRD in the coal samples. The accuracy of this method was evaluated by the correlation of calculated $\mathrm{Al}$ concentration with that determined by ICP-AES.

The digestion of international coal reference material (South African coal reference material, SARM-19) and blanks were also carried out following the same procedure to check the accuracy of the digestion and the analytical methods. Mercury concentration was determined directly on solid samples using a LECOAMA 254 gold amalgam atomic absorption spectrometer (GA-AAS, LECO Corporation, St. Joseph, CA, USA).

\section{Results}

\subsection{Coal Characterization}

Results from proximate analyses and maceral composition of coal samples from \#6 coal are summarized in Tables 1 and 2. The studied coals are characterized by medium-high moisture content (12.2-15.5\%, MT/T850-2000 [50]), high volatile matter yield (40.7-62.4\%, MT/T849-2000 [51]), and low to medium ash yield (6.8-18.4\%, GB/T15224.1-2010 [52]). According to the coalification classification of the ASTM standard [53], the studied coals are classified as lignite.

The average moisture content (14.0\%) in this study is larger than those $(8.9 \%$ and $11 \%$, respectively) reported by Dai et al. [9] and Du et al. [10], but lower than that (19.1\%) reported by Zhuang et al. [18]. The average ash yield (11.2\%) presented in this section is lower than those (17\% and $19.4 \%$, respectively) reported by Du et al. [10] and Zhuang et al. [18], but higher than that $(8.8 \%)$ reported by Dai et al. [9]. Further, the average volatile matter yield $(51.4 \%)$ is larger than those $(36.3 \%, 42 \%$, and $47.5 \%)$ reported by the authors mentioned above $[9,10,18]$.

Most coal benches in this study have high inertinite content (45-78\%, average 59\%), higher than those ( $52.5 \%$ and $<1-30 \%$, respectively) reported by Dai et al. [9] and Zhuang et al. [18], and relatively 
low huminite content (21-53\%, average $40 \%$ ), lower than those (46.8\% and 54-98\%, respectively) reported Dai et al. [9] and Zhuang et al. [18]. The inertinite macerals are mainly semifusinite, fusinite, and inertodetrinite. The dominant huminite maceral is gelinite and textinite with average contents of $18 \%$ and $13 \%$, respectively. A small proportion of attrinite and densinite are found throughout the section. Results from coal petrology in this study are similar to those from prior studies on Wulantuga coals $[9,10,18]$.

Table 1. Proximate analysis of the coal samples (wt. \%); ad, air dried; d, dry basis; daf, dry ash free.

\begin{tabular}{cccc}
\hline Sample No. & Moisture (\% ad) & Ash $(\% \mathbf{d})$ & Volatile Matter $(\%$ daf) \\
\hline WZ-01 & 15.5 & 11.1 & 52.7 \\
WZ-02 & 13.8 & 16.0 & 62.4 \\
WZ-03 & 13.9 & 12.4 & 56.0 \\
WZ-04 & 12.2 & 7.7 & 51.2 \\
WZ-05 & 15.5 & 9.6 & 46.1 \\
WZ-06 & 12.4 & 6.8 & 48.2 \\
WZ-07 & 15.5 & 7.8 & 40.7 \\
WZ-08 & 14.1 & 10.8 & 46.7 \\
WZ-09 & 12.9 & 18.4 & 59.0 \\
Average & 14.0 & 11.2 & 51.4 \\
\hline
\end{tabular}

Table 2. Maceral composition of the coal samples (vol \%).

\begin{tabular}{cccccccccccc}
\hline Sample & Tex & Att & Dens & Gel & Corp & T-Hum & Fu & Semi & Mac & Iner & T-Iner \\
\hline WZ-1 & 0.6 & 1.1 & 0.4 & 17.7 & 1.1 & 20.9 & 34.6 & 33.3 & 0.0 & 9.8 & 77.6 \\
WZ-2 & 7.0 & 5.2 & 5.4 & 14.1 & 1.2 & 32.9 & 28.0 & 17.2 & 0.0 & 19.9 & 65.2 \\
WZ-3 & 2.2 & 2.3 & 3.8 & 19.5 & 0.0 & 27.8 & 9.6 & 29.8 & 0.2 & 31.6 & 71.1 \\
WZ-4 & 15.3 & 1.2 & 6.9 & 12.5 & 1.4 & 37.3 & 27.0 & 22.0 & 0.0 & 11.5 & 60.5 \\
WZ-5 & 22.1 & 2.3 & 7.5 & 16.3 & 0.8 & 48.9 & 11.5 & 20.3 & 0.0 & 17.1 & 48.9 \\
WZ-6 & 22.7 & 1.1 & 13.1 & 15.4 & 1.1 & 53.4 & 11.8 & 14.8 & 0.0 & 18.2 & 44.8 \\
WZ-7 & 20.2 & 3.4 & 6.5 & 17.4 & 1.1 & 48.7 & 18.7 & 17.4 & 0.0 & 14.5 & 50.6 \\
WZ-8 & 11.5 & 1.8 & 3.0 & 32.2 & 0.4 & 48.8 & 10.7 & 14.8 & 0.0 & 23.7 & 49.2 \\
WZ-9 & 14.1 & 1.3 & 2.0 & 20.3 & 0.0 & 37.7 & 16.3 & 22.3 & 0.4 & 22.1 & 61.1 \\
average & 12.8 & 2.2 & 5.4 & 18.4 & 0.8 & 39.6 & 18.7 & 21.3 & 0.0 & 18.7 & 58.8 \\
\hline
\end{tabular}

Tex, Textinite; Att, Attrinite; Dens, Densinite; Gel, Gelinite; Corp, Corpohuminite; T-Hum, total huminite; Fu, Fusinite; Semi, Semifusinite; Mac, Macrinite; Iner, Inertodetrinite; T-Iner, total inertinite.

\subsection{Mineralogy}

\subsection{1. \#6 Coal}

The minerals in \#6 coal consist mainly of quartz (4.3\%), and to a lesser extent, kaolinite (1.6\%), pyrite $(1.4 \%)$, and montmorillonite $(1.9 \%)$, along with a trace of gypsum $(0.7 \%)$ (Table 3$)$ (Figure 5). In addition, trace amounts of albite, barite, chlorite, and Fe-oxide were also identified by SEM-EDX analysis (Figure 6). Quartz occurs as a dominant constituent of mineral matter in almost all the \#6 coal benches (Table 3) and is more abundant in the lowermost and uppermost coal benches compared to the middle ones (Figure 5), probably indicating an influence of detrital matter input, as reported by Ward et al. [54].

Kaolinite (Figure 6) occurs in the top and middle parts of the coal seam, while montmorillonite only in the upper part (Figure 5) (Table 3). In a few cases, chlorite was also identified in some samples (Figure 6). It contains a high Fe content and low $\mathrm{Mg}$ abundance, and thus is identified as chamosite. Previous studies concluded that chamosite is commonly formed in association with the coalification process [55-58], especially high coal rank coals. However, the studied coals are lignite and thus the chamosite may have formed by the interaction of kaolinite and Fe- $\mathrm{Mg}$ rich hydrothermal solution $[59,60]$ or smectite and K-Al rich fluid [55]. 
Pyrite distributes randomly in the coal seam and shows an inverse variation with kaolinite throughout the coal section, except for samples WZ-08 and WZ-09 (Figure 5). Pyrite and As-bearing pyrite were both observed by SEM-EDX (Figure 6). Pyrite in the coals occurs mainly as individual euhedral crystals (Figure 6C) and secondarily as framboidal aggregates (Figure 6E) and disseminated particles (Figure 6F), indicating its formation during early diagenesis stage [61,62]. In a few cases, pyrite is commonly found as dissolved pyrite crystals and agglomerate partially or totally oxidized to Fe-oxides (Figure 6), probably as a result of oxidation of samples near the surface.

Gypsum occurs in all the coal seam and is randomly distributed throughout the coal seam (Figure 5).

Table 3. Semi-quantitative mineral composition of the studied coals, coalified trunks, roof glutenites, and pyrite mineralization (wt. \% db). C, coal, T trunk, R, glutinite-roof.

\begin{tabular}{cccccccccc}
\hline Sample No. & Mnt & Ill & Kln & Qtz & Mc & Ab & Py & Mlt & Gp \\
\hline WZ-01 C & 1.9 & nd & nd & 5.1 & nd & nd & 1.5 & nd & 1.3 \\
WZ-02 C & 9.2 & nd & 2.2 & 2.2 & nd & nd & 0.2 & nd & 0.4 \\
WZ-03 C & 4.8 & nd & 1.1 & 4.1 & nd & nd & 0.4 & nd & 0.7 \\
WZ-04 C & nd & nd & nd & 3.2 & nd & nd & 3.2 & nd & 0.6 \\
WZ-05 C & 1.3 & nd & 3.0 & 3.7 & nd & nd & 0.3 & nd & 0.4 \\
WZ-06 C & nd & nd & nd & 2.6 & nd & nd & 2.4 & nd & 0.9 \\
WZ-07 C & nd & nd & 3.1 & 2.6 & nd & nd & 0.1 & nd & 0.9 \\
WZ-08 C & nd & nd & 1.8 & 5.4 & nd & nd & 2.0 & nd & 0.4 \\
WZ-09 C & nd & nd & 2.8 & 10.1 & nd & nd & 2.8 & nd & 0.5 \\
WLTG-01 T & nd & nd & nd & 11.8 & nd & nd & 6.7 & 20.2 & 3.4 \\
WLTG-02 R & 8.1 & 0.8 & 3.2 & 57.0 & 11.3 & 14.0 & 0.2 & nd & 0.5 \\
WLTG-03 T & nd & nd & nd & nd & nd & nd & 5.0 & 12.6 & 0.6 \\
WLTG-04 R & nd & 0.8 & 0.2 & 25.8 & 11.1 & 28.1 & 0.4 & 0.8 & 0.6 \\
WLTG-PY & nd & nd & nd & nd & nd & nd & 53.0 & nd & nd \\
\hline
\end{tabular}

Mnt, montmorillonite; Ill. Illite; Kln, kaolinite; Qtz, quartz; Mc, microcline; Ab, albite; Py, pyrite; Mlt, melanterite; $\mathrm{Gp}$, gypsum; nd, no data.

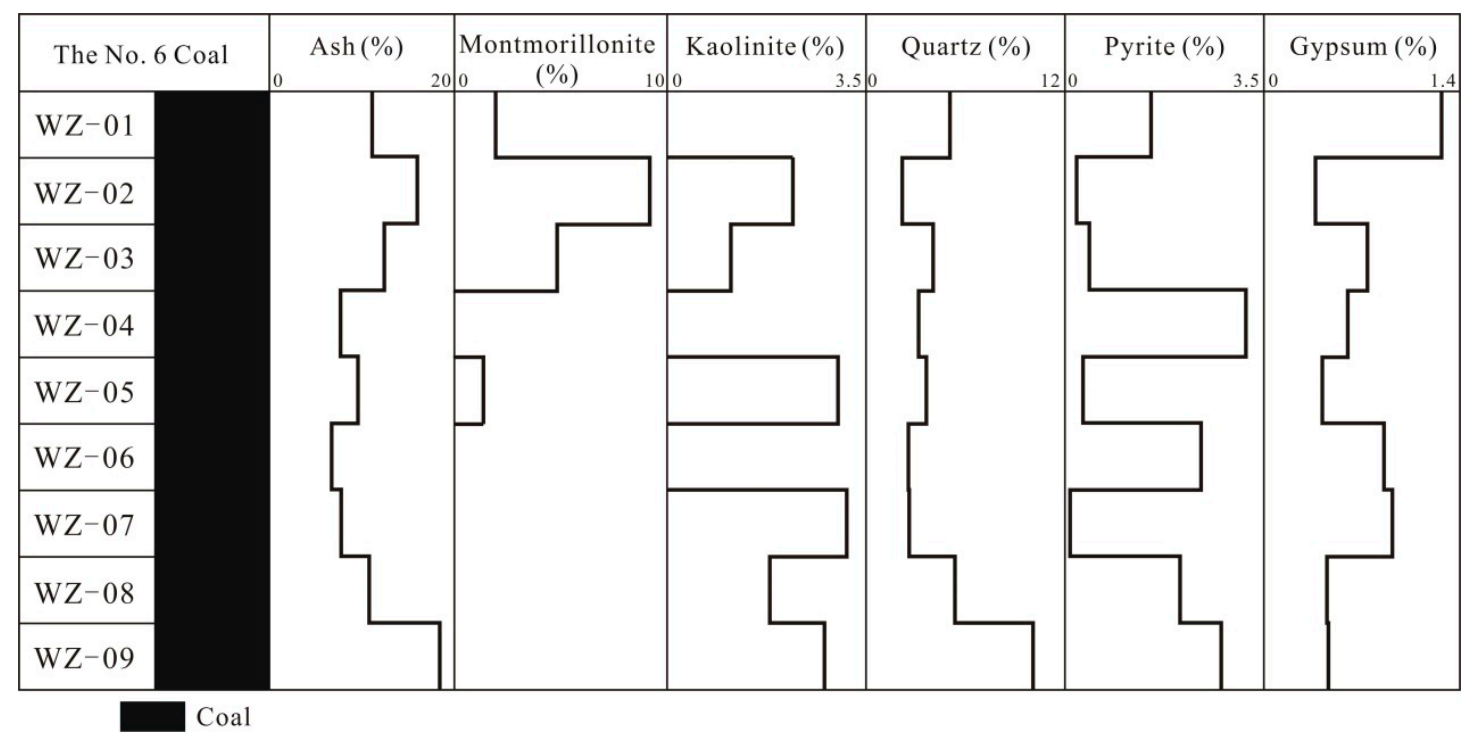

Figure 5. Vertical variations of ash yield and minerals through the No.6 Coal section (wt. \%). 

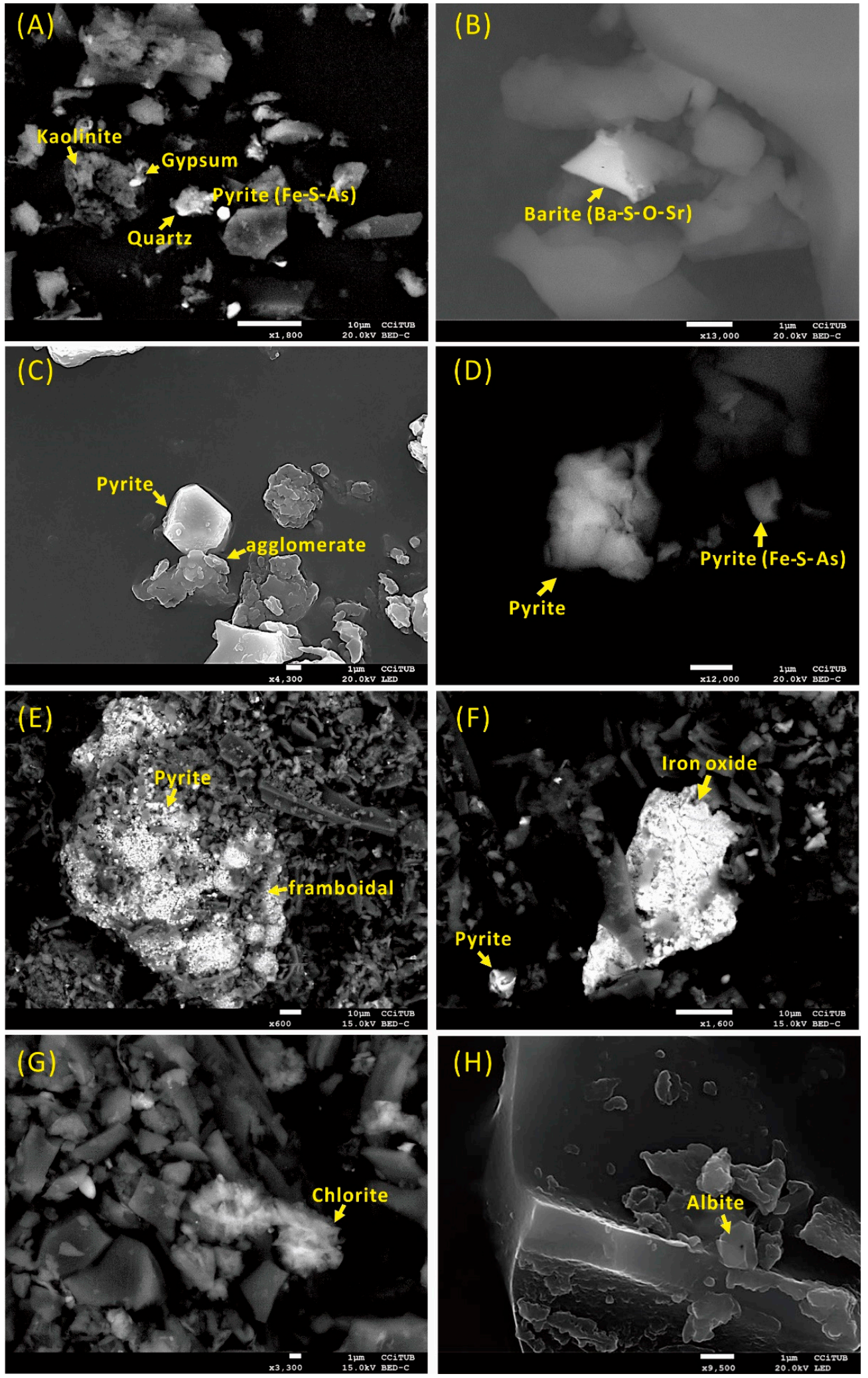

Figure 6. SEM back-scattered electron images of coal samples from WZ profile. (A), kaolinite, gypsum, pyrite, and quartz in sample WZ-01. (B), Sr-bearing barite in sample WZ-01. (C), agglomerate of framboidal pyrite and partially dissolved pyrite in sample WZ-01. (D), pyrite and As-bearing pyrite in sample WZ-01. (E), framboidal pyrite in sample WZ-03. (F), disseminated pyrite and iron oxide in sample WZ-03. (G), chlorite in sample WZ-03. (H), albite in sample WZ-01. 


\subsubsection{Coalified Trunks}

Minerals present in the coalified trunk samples are mainly melanterite $(16.4 \%)$, and to a lesser extent, pyrite (5.9\%), and gypsum (2.0\%) (Table 3). Quartz is only present in the sample WLTG-03. Clay minerals such as kaolinite and chlorite are observed by SEM-EDX analysis, although below the XRD detection limit level (Figure 7). The contents of these minerals in WLTG-01 from the outer part of the coalified trunk (Figure 4) are higher than that from the central part of the coalified trunk. From a macro perspective, these coalized trunks are obviously mineralized.

Pyrite in coalified trunks occurs as disseminated euhedral crystals (Figure 7), which are indicative of an early-epigenetic origin [61,62]. SEM-EDX analysis also evidenced the very frequent occurrence of globular Fe sulfide particles and high As-pyrite, and there are some crystal aggregates of these particles totally or partially dissolved with the morphology of pyrite (Figure 7). There are also partially dissolved pyrite crystals detected in melanterite ( $\mathrm{Fe}-\mathrm{S}-\mathrm{O})$ or magnesiocopiapite $(\mathrm{Fe}-\mathrm{Mg}-\mathrm{S}-\mathrm{O})$ (Figure 8). The occurrences of Fe-bearing minerals mentioned above indicate that pyrite in the coalified trunk may have been subjected to oxidization $[63,64]$. Elemental sulfur was also detected by SEM-EDX (Figure 7), which is another product from the oxidation of pyrite [36,62].

Melanterite is present at relatively high concentrations in the coalified trunks (Figure 8 and Table 5). Melanterite is a hydrated ferrous mineral and occurs commonly in weathered coals as an oxidation product of pyrite [62,64]. The varying contents of melanterite in WLTG-01 $(20.2 \%)$ and WLTG-03 (12.6\%) indicate different weathering degrees between them. Under SEM-EDX analysis, melanterite, and to a lesser extent, Fe-oxides contain relatively high contents of As and Sb (Figure 8). Furthermore, Mg-Al-bearing Fe sulfates were also detected by SEM-EDX (Figure 8). These sulfates were also reported in the previously-published literature [64].

Gypsum occurs as lath-like crystals within the organic matrix in the coalified trunk (Figure 8), indicating an epigenetic origin $[65,66]$. Syngenetic gypsum can also be found in coals influenced by sea water [67]. In this study, gypsum content in WLTG-01 is the highest (3.4\%) compared to the other samples, probably because WLTG-01 is in the outer part of the coalified trunk and is most likely to be oxidized.

Chlorite, although below the detection limit of XRD analysis, in a few cases, is detected by SEM-EDX in the coalified trunk (Figure 7). 

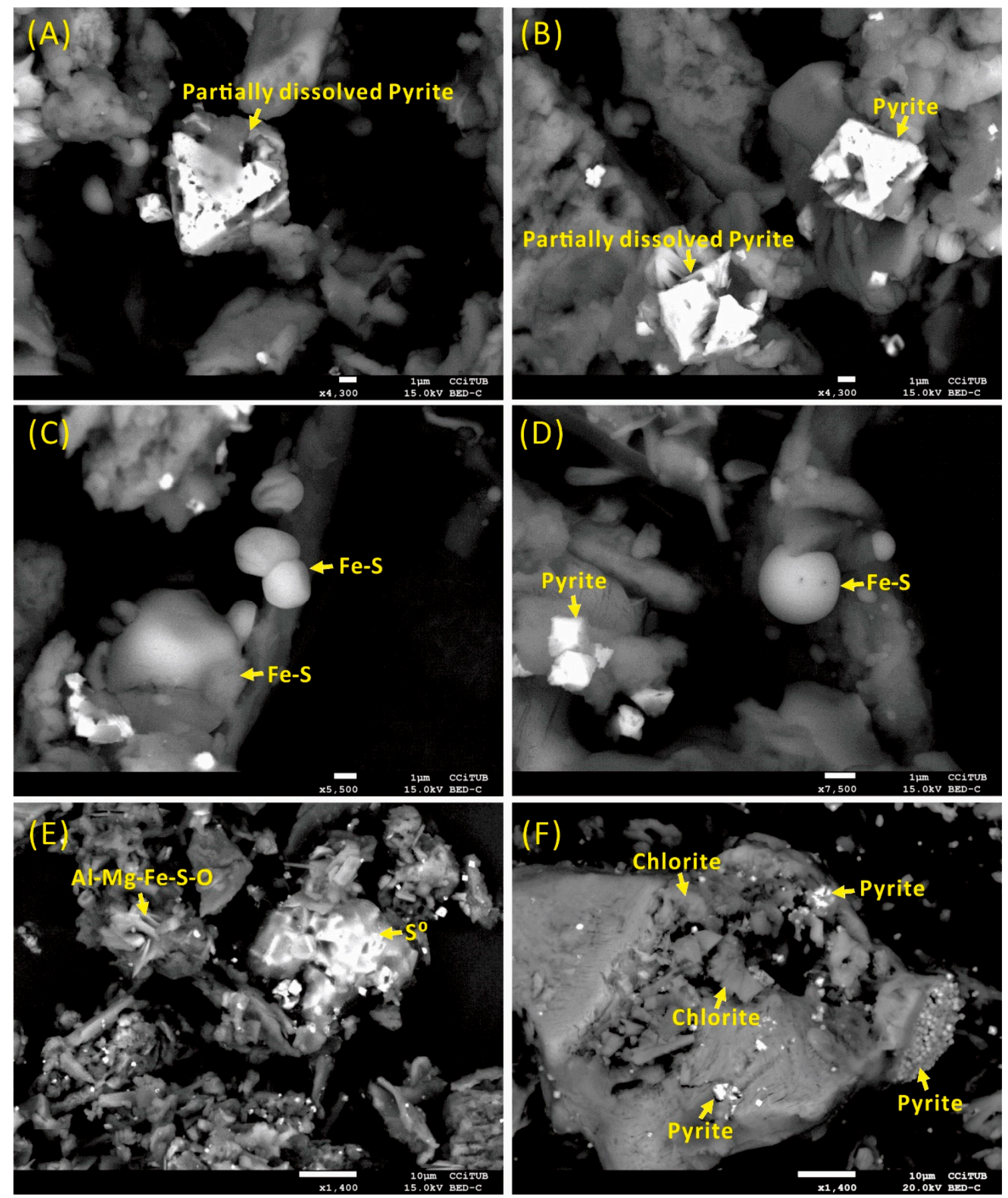

Figure 7. SEM back-scattered electron images of coalified trunk samples from Wulantuga open-pit mine. (A), partially dissolved pyrite in sample WLTG-03. (B), partially dissolved pyrite and pyrite in sample WLTG-03. (C), globular Fe sulfide particles in sample WLTG-03. (D), pyrite and globular Fe sulfide particle in sample WLTG-03. (E), Al-Mg-Fe sulfate and elemental sulfur in sample WLTG-03. (F), chlorite and pyrite in sample WLTG-01. 

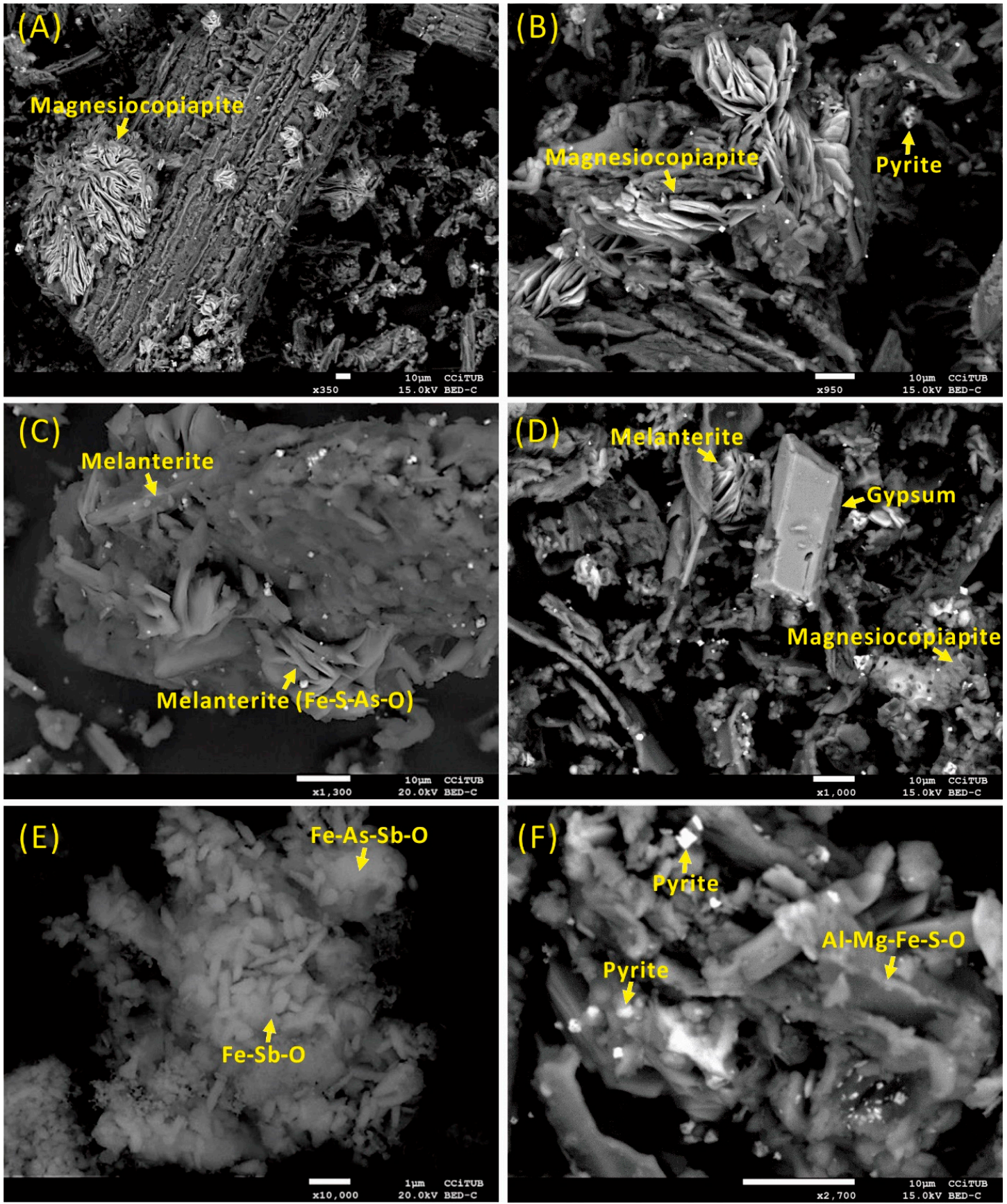

Figure 8. SEM back-scattered electron images of coalified trunk samples from Wulantuga open-pit mine. (A), magnesiocopiapite in sample WLTG-03. (B), magnesiocopiapite and pyrite in sample WLTG-03. (C), melanterite and As-bearing melanterite in sample WLTG-01. (D), gypsum, melanterite and magnesiocopiapite in sample WLTG-03. (E), Sb-bearing and Sb-As-bearing iron oxide in sample WLTG-03. (F), pyrite and Al-Mg-Fe sulfate in sample WLTG-03.

\subsection{3. \#6 Coal Roof Samples}

The roof samples (WLTG-02, WLTG-04) from the glutenite bed overlaying \#6 coal are dominantly composed of quartz $(41.4 \%)$, albite $(21.0 \%)$ and microcline $(11.2 \%)$, with minor amounts of montmorillonite $(4.0 \%)$ and kaolinite $(1.7 \%)$, as well as trace amounts of illite $(0.8 \%)$, gypsum $(0.6 \%)$, melanterite $(0.4 \%)$, and pyrite $(0.3 \%)$ (Table 3$)$. 


\subsection{Geochemistry}

\subsubsection{Major Elements}

The concentrations of major and trace elements of the samples in this study are summarized in Table 4. The abundances of major elements of the studied coal samples are close to those of Chinese coals reported by Dai et al. [3] and of other Wulantuga coals (MY and M2, 3, and 4 profiles reported by Zhuang et al. [18] and Du et al. [10]).

Aluminum has a significant positive correlation with ash yield $(r=0.94)$ (Table 5), indicating an inorganic affinity. Iron and S have a significant positive correlation $(\mathrm{r}=0.97)$, and $\mathrm{Fe} / \mathrm{S}$ ratio $(0.81)$ is similar to the theoretical value for pyrite crystal $(0.87)$, indicating they were most likely present in pyrite.

The coalified trunk samples are highly enriched in $\mathrm{Fe}, \mathrm{S}$, and $\mathrm{Mg}$, which is in accordance with the high amounts of pyrite and Mg-bearing melanterite (Figure 8). Aluminum, K, Ca and Na contents of WLTG-01 are higher than that of WLTG-03, which may be related to relatively high aluminum-silicate phases and gypsum contents in WLTG-01. The roof samples have relatively high $\mathrm{Al}, \mathrm{K}, \mathrm{Na}$ content, and relatively low Ca content compared to the coal samples.

\subsubsection{Trace Elements}

Thew concentration coefficient ( $\mathrm{CC}=$ ratio of element concentration in investigated coals vs. world coals [68], which was proposed by Dai et al. [69]) is used in the study to determine the enrichment or depletion of trace elements (Figure 9). Compared to the average values for world coals [68], $\mathrm{W}$ is unsually enriched, with a CC $>100$, while Ge, As, and Be are significantly enriched $(10<C C<100)$. $\mathrm{Hg}$, $\mathrm{Sb}$, and $\mathrm{Cs}$ are enriched $(5<\mathrm{CC}<10)$, while $\mathrm{Li}, \mathrm{B}, \mathrm{P}, \mathrm{Sr}, \mathrm{Y}, \mathrm{Zr}$, and $\mathrm{Lu}$ are normal $(0.5<\mathrm{CC}<2)$. The remaining elements are depleted $(C C<0.5)$ compared to the world coals [68].

The coalified trunk sample from the central part (WLTG-03) contains very high Ge (1381 mg/kg), As $(2889 \mathrm{mg} / \mathrm{kg}), \mathrm{Sb}(1231 \mathrm{mg} / \mathrm{kg}), \mathrm{W}(188 \mathrm{mg} / \mathrm{kg})$, and $\mathrm{Hg}(15 \mathrm{mg} / \mathrm{kg})$ contents. The content of Ge and As in the outer part of the coalified trunk sample (WLTG-01) is significantly lower than that in the central part of the coalified trunk, while the contents of $\mathrm{Sb}, \mathrm{Hg}, \mathrm{Sr}, \mathrm{Rb}, \mathrm{Ba}$, and $\mathrm{Pb}$ are significantly higher than those in the central of the coalified trunk. The contents of Ti, V, Cr, Co, Ni, Zn, Ga, Ge, As, $\mathrm{Zr}, \mathrm{Nb}$, Mo, Se, Sn, Sb, Th, and Hg in WLTG-01 and WLTG-03 are significantly higher than the average contents in the coal seam profile in this study. A similar enrichment of a number of trace elements was also found in coalified trunks by Du et al. [10].

The roof sample (WLTG-02) is significantly enriched in $\mathrm{Li}, \mathrm{Sc}, \mathrm{Ti}, \mathrm{V}, \mathrm{Cr}, \mathrm{Ni}, \mathrm{Ga}, \mathrm{Rb}, \mathrm{Zr}, \mathrm{Nb}, \mathrm{Sb}, \mathrm{Cs}$, $\mathrm{Ba}, \mathrm{Pb}, \mathrm{Th}$, and $\mathrm{Hg}$ when compared to the average value of the coal samples, and depleted in $\mathrm{Be}, \mathrm{B}, \mathrm{P}$, $\mathrm{Ge}$, As and W. Furthermore, the roof sample WLTG-04 adjacent to the coalified trunk contains higher contents of $\mathrm{Ge}$, As, and $\mathrm{Sb}$ than another roof sample, WLTG-02, distal to the coalified trunk.

The modes of occurrence of trace elements in this study are similar to those reported by previous studies $[9,10,18]$ : Germanium and $\mathrm{W}$ have a positive correlation coefficient with each other $(r=0.85)$, and they all have high negative correlation coefficients with ash $(r=-0.72$ and -0.73 , respectively), indicating an organic affinity. Arsenic, $\mathrm{Sb}$, and $\mathrm{Hg}$ have relatively significant correlation with ash $(\mathrm{r}=-0.31,-0.51$, and -0.46 , respectively) and slightly correlation with $\mathrm{Fe}(\mathrm{r}=0.31,0.06$, and 0.09 , respectively), probably indicating a multiple source such as organic matter and pyrite, which is also attested to by the pyrite veins sample from the coal fractures (WLTG-PY) having the highest As content $(3097 \mathrm{mg} / \mathrm{kg})$. The correlation coefficients of Be-ash $(\mathrm{r}=0.16)$ and Be-Ca $(\mathrm{r}=0.63)$ suggest an association between Be and carbonate minerals. Cesium has a high correlation coefficient with ash $(r=0.69)$, suggesting an inorganic affinity. 
Table 4. Major and trace element contents in the Wulantuga coals, roof samples and coalified trunks (mg/kg db) and comparison with the worldwide and Chinese usual concentration ranges in coal.

\begin{tabular}{|c|c|c|c|c|c|c|c|c|c|c|c|c|c|c|c|c|c|}
\hline \multirow{2}{*}{$\mathrm{mg} / \mathrm{kg}$} & \multicolumn{10}{|c|}{ Wulantuga \#6 Coal SAMPLES } & \multicolumn{2}{|c|}{ Carbonized Trunks } & \multicolumn{2}{|c|}{ Roof } & \multirow{2}{*}{$\begin{array}{c}\text { Mineral } \\
\text { WLTG-PY }\end{array}$} & \multirow{2}{*}{ World $^{b}$} & \multirow{2}{*}{ China $^{c}$} \\
\hline & WZ-01 & WZ-02 & WZ-03 & WZ-04 & WZ-05 & WZ-06 & WZ-07 & WZ-08 & WZ-09 & WA & WLTG-01 & WLTG-03 & WLTG-02 & WLTG-04 & & & \\
\hline $\mathrm{Si}^{\mathrm{a}}$ & 2.98 & 3.53 & 3.30 & 1.84 & 2.86 & 1.59 & 2.22 & 3.11 & 5.26 & 2.97 & 5.43 & 0.51 & 33.59 & 22.41 & 0.51 & nd & 3.95 \\
\hline $\mathrm{Al}^{\mathrm{a}}$ & 0.47 & 1.28 & 0.79 & 0.36 & 0.68 & 0.37 & 0.50 & 0.51 & 1.62 & 0.7 & 2.37 & 0.81 & 5.22 & 3.65 & 0.17 & nd & 1.58 \\
\hline $\mathrm{Ca}^{\mathrm{a}}$ & 1.11 & 1.26 & 0.95 & 0.67 & 0.65 & 0.79 & 0.98 & 0.88 & 0.83 & 0.9 & 0.73 & 0.28 & 0.23 & 0.39 & 0.11 & nd & 0.88 \\
\hline $\mathrm{Fe}^{\mathrm{a}}$ & 1.15 & 0.82 & 0.93 & 1.56 & 1.11 & 0.91 & 0.70 & 2.12 & 1.85 & 1.2 & 10.1 & 10.1 & 1.19 & 2.74 & 45.7 & nd & 1.70 \\
\hline $\mathrm{K}^{\mathrm{a}}$ & 0.00 & 0.31 & 0.00 & 0.10 & 0.06 & 0.14 & 0.19 & 0.07 & 0.17 & 0.1 & 0.51 & 0.06 & 1.89 & 1.37 & 0.00 & nd & 0.08 \\
\hline $\mathrm{Mg}^{\mathrm{a}}$ & 0.34 & 0.39 & 0.30 & 0.15 & 0.17 & 0.17 & 0.23 & 0.23 & 0.28 & 0.3 & 0.64 & 0.56 & 0.33 & 0.43 & 0.03 & nd & 0.13 \\
\hline $\mathrm{Na}{ }^{a}$ & 0.10 & 0.05 & 0.02 & 0.03 & 0.03 & 0.04 & 0.09 & 0.10 & 0.07 & 0.1 & 0.31 & 0.11 & 1.04 & 0.60 & 0.01 & nd & 0.06 \\
\hline $\mathrm{S}^{\mathrm{a}}$ & 1.67 & 0.98 & 1.00 & 1.94 & 1.45 & 1.24 & 0.85 & 2.54 & 2.00 & 1.5 & 11.1 & 11.5 & 0.66 & 2.86 & 51.4 & nd & nd \\
\hline $\mathrm{Li}$ & 6.5 & 19.6 & 13.2 & 3.1 & 4.1 & 1.4 & 1.4 & 1.9 & 7.0 & 6.5 & 10.9 & 3.8 & 19.3 & 15.1 & 0.1 & 12 & 31.8 \\
\hline $\mathrm{Be}$ & 33.1 & 28.8 & 27.6 & 15.3 & 12.9 & 15.2 & 8.6 & 6.7 & 6.7 & 17.2 & 2.0 & 2.8 & 1.0 & 2.6 & 0.1 & 1.6 & 2.1 \\
\hline B & 105 & 57.3 & 51.0 & 74.3 & 97.1 & 81.4 & 105 & 183 & 94.7 & 94.3 & 80.2 & 23.9 & 13.8 & 24.9 & 116 & 52 & 53.0 \\
\hline $\mathrm{P}$ & 0.0 & 1002 & 93.9 & 295 & 0.0 & 562.3 & 414 & 48.3 & 0.0 & 268 & 73.8 & 88.7 & 69.1 & 138.2 & 0.0 & 231 & 401.7 \\
\hline Sc & 0.1 & 0.1 & 0.1 & 0.1 & 0.1 & 0.1 & 0.1 & 0.1 & 1.2 & 0.2 & 1.1 & 0.1 & 2.9 & 3.6 & 0.1 & 3.9 & 4.4 \\
\hline $\mathrm{Ti}$ & 353 & 840 & 540 & 169 & 402 & 154 & 221.4 & 322.1 & 605 & 401 & 1631 & 1520 & 2248 & 1802 & 54.3 & 798 & 1685 \\
\hline V & 4.8 & 6.2 & 6.8 & 4.1 & 6.8 & 4.7 & 3.7 & 5.5 & 16.8 & 6.6 & 58.7 & 96.7 & 28.7 & 67.5 & 2.4 & 25 & 35.1 \\
\hline $\mathrm{Cr}$ & 3.7 & 6.2 & 5.5 & 2.5 & 4.0 & 4.6 & 2.3 & 3.1 & 10.2 & 4.7 & 17.4 & 16.4 & 20.5 & 39.2 & $<\mathrm{dl}$ & 16 & 15.4 \\
\hline $\mathrm{Mn}$ & 65.2 & 68.3 & 61.7 & 41.9 & 45.4 & 55.3 & 75.9 & 64.2 & 58.9 & 59.6 & 60.8 & 58.0 & 69.4 & 42.6 & 13.5 & 85 & 271.2 \\
\hline Co & $<\mathrm{dl}$ & $<\mathrm{dl}$ & $<\mathrm{dl}$ & $<\mathrm{dl}$ & 0.9 & 1.6 & 1.5 & 2.3 & 4.5 & 2.1 & 37.8 & 29.8 & 3.7 & 29.5 & 4.4 & 5.1 & 7.1 \\
\hline $\mathrm{Ni}$ & 1.3 & 1.8 & 2.0 & 2.2 & 1.8 & 2.7 & 2.7 & 2.5 & 2.5 & 2.2 & 64.8 & 65.0 & 7.1 & 22.1 & 3.9 & 13 & 13.7 \\
\hline $\mathrm{Cu}$ & 4.3 & 7.0 & 6.5 & 3.0 & 7.6 & 2.9 & 12.8 & 4.1 & 11.6 & 6.7 & 14.3 & 10.1 & 7.1 & 16.7 & 6.7 & 16 & 17.5 \\
\hline $\mathrm{Zn}$ & 20.1 & 37.0 & 18.4 & 18.5 & 14.7 & 17.1 & 22.1 & 21.1 & 26.8 & 21.7 & 45.7 & 38.6 & 21.9 & 32.5 & 37.6 & 23 & 41.4 \\
\hline $\mathrm{Ga}$ & 0.9 & 5.2 & 1.7 & 1.4 & 1.5 & $<\mathrm{dl}$ & 1.0 & 1.2 & 3.4 & 2.0 & 7.9 & 6.9 & 8.8 & 7.7 & 0.1 & 5.8 & 6.6 \\
\hline $\mathrm{Ge}$ & 79.7 & 43.8 & 127 & 492 & 387 & 362 & 138 & 121 & 23 & 197 & 597 & 1381 & 2.7 & 138 & 14.1 & 2.2 & 2.8 \\
\hline As & 259 & 139 & 200 & 476 & 475 & 233 & 118 & 236 & 234 & 263 & 1673 & 2889 & 153 & 601 & 3097 & 8.3 & 3.8 \\
\hline $\mathrm{Se}$ & $<\mathrm{dl}$ & $<\mathrm{dl}$ & $<\mathrm{dl}$ & $<\mathrm{dl}$ & $<\mathrm{dl}$ & $<\mathrm{dl}$ & $<\mathrm{dl}$ & $<\mathrm{dl}$ & $<\mathrm{dl}$ & $<\mathrm{dl}$ & 3.5 & 5.0 & $<\mathrm{dl}$ & 0.9 & 1.8 & 1.3 & 2.5 \\
\hline $\mathrm{Rb}$ & 2.0 & 3.6 & 2.0 & 1.3 & 3.5 & 1.6 & 2.4 & 3.7 & 15.2 & 3.9 & 26.9 & 5.4 & 78.1 & 55.3 & 3.9 & 14 & 9.3 \\
\hline $\mathrm{Sr}$ & 81.4 & 142 & 80.8 & 55.3 & 54.9 & 59.5 & 73.7 & 65.5 & 64.6 & 75.2 & 119 & 53.1 & 87.1 & 79.3 & 11.7 & 110 & 140.0 \\
\hline Y & 9.3 & 9.6 & 5.1 & 1.7 & 2.4 & 1.7 & 2.1 & 2.6 & 5.9 & 4.5 & 6.1 & 5.1 & 7.5 & 9.0 & 1.6 & 8.4 & 18.2 \\
\hline $\mathrm{Zr}$ & 11.9 & 126 & 35.0 & 7.2 & 12.1 & 5.5 & 7.2 & 9.7 & 25.4 & 26.7 & 81.7 & 88.6 & 82.1 & 65.5 & 3.3 & 36 & 89.5 \\
\hline $\mathrm{Nb}$ & 1.3 & 5.3 & 2.5 & 0.1 & 1.4 & 0.1 & 0.1 & 0.9 & 1.5 & 1.5 & 5.1 & 6.9 & 4.5 & 2.8 & 0.1 & 3.7 & 9.4 \\
\hline Mo & $<\mathrm{dl}$ & $<\mathrm{dl}$ & $<\mathrm{dl}$ & $<\mathrm{dl}$ & $<\mathrm{dl}$ & $<\mathrm{dl}$ & $<\mathrm{dl}$ & $<\mathrm{dl}$ & $<\mathrm{dl}$ & $<\mathrm{dl}$ & 2.3 & 2.6 & $<\mathrm{dl}$ & 1.9 & 2.2 & 2.2 & 3.1 \\
\hline $\mathrm{Cd}$ & $<\mathrm{dl}$ & $<\mathrm{dl}$ & $<\mathrm{dl}$ & $<\mathrm{dl}$ & $<\mathrm{dl}$ & $<\mathrm{dl}$ & $<\mathrm{dl}$ & $<\mathrm{dl}$ & $<\mathrm{dl}$ & $<\mathrm{dl}$ & $<\mathrm{dl}$ & $<\mathrm{dl}$ & $<\mathrm{dl}$ & $<\mathrm{dl}$ & $<\mathrm{dl}$ & 0.22 & 0.3 \\
\hline Sn & 0.1 & 1.1 & 0.1 & 0.1 & 0.2 & 0.1 & 0.1 & 0.1 & 0.3 & 0.3 & 3.2 & 3.7 & 0.8 & 2.1 & 0.1 & 1.1 & 2.1 \\
\hline $\mathrm{Sb}$ & 0.8 & 0.1 & 0.1 & 24.0 & 19.0 & 9.3 & 0.1 & 0.1 & 0.1 & 6.0 & 1448 & 1231 & 38.9 & 387 & 0.1 & 0.92 & 0.8 \\
\hline Cs & 3.6 & 4.6 & 3.8 & 4.1 & 5.1 & 3.8 & 4.3 & 5.2 & 14.8 & 5.5 & 17.7 & 8.6 & 16.2 & 19.1 & 18.7 & 1.0 & 1.1 \\
\hline Ba & 48.7 & 143 & 45.3 & 26.1 & 22.3 & 39.9 & 27.8 & 63.0 & 44.5 & 51.2 & 389 & 14.3 & 343 & 236 & 13.9 & 150 & 159.0 \\
\hline
\end{tabular}


Table 4. Cont.

\begin{tabular}{|c|c|c|c|c|c|c|c|c|c|c|c|c|c|c|c|c|c|}
\hline \multirow{2}{*}{$\mathrm{mg} / \mathrm{kg}$} & \multicolumn{10}{|c|}{ Wulantuga \#6 Coal SAMPLES } & \multicolumn{2}{|c|}{ Carbonized Trunks } & \multicolumn{2}{|c|}{ Roof } & \multirow{2}{*}{$\begin{array}{c}\text { Mineral } \\
\text { WLTG-PY }\end{array}$} & \multirow{2}{*}{ World $^{b}$} & \multirow{2}{*}{ China ${ }^{c}$} \\
\hline & WZ-01 & WZ-02 & WZ-03 & WZ-04 & WZ-05 & WZ-06 & WZ-07 & WZ-08 & WZ-09 & WA & WLTG-01 & WLTG-03 & WLTG-02 & WLTG-04 & & & \\
\hline $\mathrm{La}$ & 4.1 & 15.7 & 6.3 & 2.2 & 3.0 & 2.0 & 3.1 & 3.5 & 6.3 & 5.1 & 9.5 & 5.9 & 10.7 & 12.0 & 0.1 & 11 & 22.5 \\
\hline $\mathrm{Ce}$ & 9.6 & 28.5 & 12.4 & 4.2 & 5.9 & 4.2 & 5.6 & 6.9 & 12.9 & 10.0 & 21.2 & 13.6 & 23.0 & 26.8 & 2.2 & 23 & 46.7 \\
\hline $\operatorname{Pr}$ & 1.2 & 2.9 & 1.3 & 0.1 & 0.1 & 0.1 & 0.1 & 0.8 & 1.4 & 0.9 & 2.3 & 1.5 & 2.5 & 3.0 & 0.1 & 3.5 & 6.4 \\
\hline $\mathrm{Nd}$ & 4.9 & 9.9 & 4.8 & 1.7 & 2.4 & 1.8 & 2.2 & 3.0 & 5.4 & 4.0 & 8.6 & 5.6 & 9.0 & 11.5 & 1.1 & 12 & 22.3 \\
\hline $\mathrm{Sm}$ & 1.0 & 1.9 & 0.9 & 0.1 & 0.1 & 0.1 & 0.1 & 0.1 & 1.1 & 0.6 & 1.8 & 1.3 & 1.8 & 2.5 & 0.1 & 2.0 & 4.1 \\
\hline $\mathrm{Eu}$ & 0.1 & 0.1 & 0.1 & 0.1 & 0.1 & 0.1 & 0.1 & 0.1 & 0.1 & 0.1 & 0.1 & 0.1 & 0.1 & 0.1 & 0.1 & 0.47 & 0.8 \\
\hline $\mathrm{Gd}$ & 1.1 & 2.0 & 1.0 & 0.1 & 0.1 & 0.1 & 0.1 & 0.1 & 1.2 & 0.6 & 1.7 & 1.3 & 1.8 & 2.5 & 0.1 & 2.7 & 4.7 \\
\hline $\mathrm{Tb}$ & 0.1 & 0.1 & 0.1 & 0.1 & 0.1 & 0.1 & 0.1 & 0.1 & 0.1 & 0.1 & 0.1 & 0.1 & 0.1 & 0.1 & 0.1 & 0.32 & 0.6 \\
\hline Dy & 1.0 & 1.9 & 0.1 & 0.1 & 0.1 & 0.1 & 0.1 & 0.1 & 1.0 & 0.5 & 1.3 & 1.2 & 1.5 & 2.1 & 0.1 & 2.1 & 3.7 \\
\hline Ho & 0.1 & 0.1 & 0.1 & 0.1 & 0.1 & 0.1 & 0.1 & 0.1 & 0.1 & 0.1 & 0.1 & 0.1 & 0.1 & 0.1 & 0.1 & 0.54 & 1.0 \\
\hline Er & 0.1 & 1.1 & 0.1 & 0.1 & 0.1 & 0.1 & 0.1 & 0.1 & 0.1 & 0.2 & 0.1 & 0.1 & 0.9 & 1.1 & 0.1 & 0.93 & 1.8 \\
\hline $\mathrm{Tm}$ & 0.1 & 0.1 & 0.1 & 0.1 & 0.1 & 0.1 & 0.1 & 0.1 & 0.1 & 0.1 & 0.1 & 0.1 & 0.1 & 0.1 & 0.1 & 0.31 & 0.6 \\
\hline $\mathrm{Yb}$ & 0.1 & 1.0 & 0.1 & 0.1 & 0.1 & 0.1 & 0.1 & 0.1 & 0.1 & 0.2 & 0.1 & 0.1 & 0.9 & 1.0 & 0.1 & 1.0 & 2.1 \\
\hline $\mathrm{Lu}$ & 0.1 & 0.1 & 0.1 & 0.1 & 0.1 & 0.1 & 0.1 & 0.1 & 0.1 & 0.1 & 0.1 & 0.1 & 0.1 & 0.1 & 0.1 & 0.2 & 0.4 \\
\hline $\mathrm{Hf}$ & 0.1 & 3.4 & 1.0 & 0.1 & 0.1 & 0.1 & 0.1 & 0.1 & 0.1 & 0.6 & 1.7 & 0.1 & 3.0 & 1.8 & 0.1 & 1.2 & 3.7 \\
\hline $\mathrm{Ta}$ & 0.1 & 0.1 & 0.1 & 0.1 & 0.1 & 0.1 & 0.1 & 0.1 & 0.1 & 0.1 & 0.1 & 0.1 & 0.1 & 0.1 & 0.1 & 0.28 & 0.6 \\
\hline W & 91.9 & 76.8 & 162 & 485 & 486 & 526 & 355 & 349 & 217 & 305 & 189 & 188 & 52.0 & 67.8 & 80.9 & 1.1 & 1.1 \\
\hline $\mathrm{Tl}$ & 0.1 & 0.1 & 0.1 & 0.1 & 0.1 & 0.1 & 0.1 & 0.1 & 0.1 & 0.1 & 0.1 & 0.1 & 0.1 & 0.1 & 2.9 & 0.63 & 0.5 \\
\hline $\mathrm{Pb}$ & 1.5 & 6.2 & 2.2 & 1.2 & 1.9 & 0.8 & 1.8 & 1.2 & 4.3 & 2.3 & 8.0 & 2.2 & 9.7 & 12.7 & 3.9 & 7.8 & 15.1 \\
\hline $\mathrm{Bi}$ & 0.1 & 0.1 & 0.1 & 0.1 & 0.1 & 0.1 & 0.1 & 0.1 & 0.1 & 0.1 & 0.1 & 0.1 & 0.1 & 0.1 & 0.1 & 0.97 & 0.8 \\
\hline Th & 1.2 & 4.3 & 1.5 & 0.1 & 1.2 & 0.1 & 0.1 & 1.1 & 3.3 & 1.4 & 6.1 & 7.7 & 5.5 & 8.1 & 0.1 & 3.3 & 5.8 \\
\hline $\mathrm{U}$ & $<\mathrm{dl}$ & $<\mathrm{dl}$ & $<\mathrm{dl}$ & $<\mathrm{dl}$ & $<\mathrm{dl}$ & $<\mathrm{dl}$ & $<\mathrm{dl}$ & $<\mathrm{dl}$ & $<\mathrm{dl}$ & $<\mathrm{dl}$ & 1.0 & 1.3 & 1.0 & 1.8 & 0.1 & 2.4 & 2.4 \\
\hline $\mathrm{Hg}$ & 1.1 & 0.1 & 0.0 & 2.5 & 1.8 & 0.6 & 0.1 & 0.1 & 0.1 & 0.7 & 32.3 & 15.3 & 2.7 & 3.8 & 0.4 & 0.1 & 0.2 \\
\hline
\end{tabular}

${ }^{\mathrm{a}}$ Concentrations in wt. \% (otherwise in $\mathrm{mg} / \mathrm{kg}$ ); ${ }^{\mathrm{b}}$ Average concentrations of elements in the world coals [68]; ${ }^{\mathrm{c}}$ Average concentrations of elements in the common Chinese coals [3]; < dl, under detected limit. 


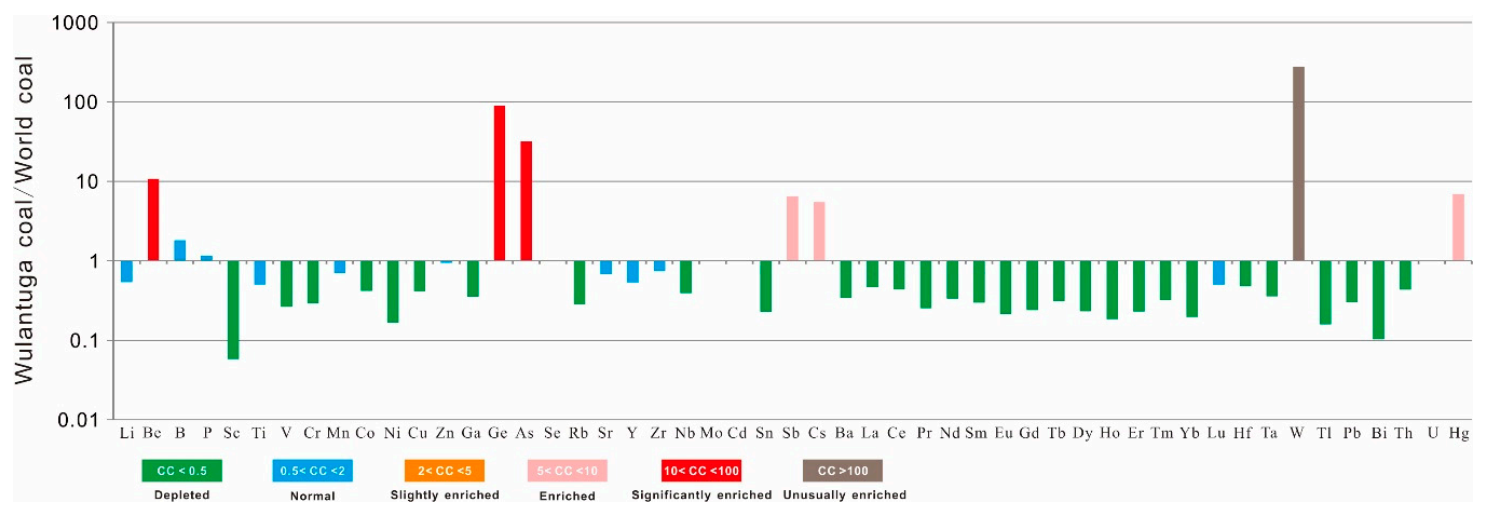

Figure 9. Concentration coefficients (CC) of trace elements in the high Ge Wulantuga coal vs. the world coal (the average concentration of trace elements from world coal reported by Ketris and Yudovich [68]).

Table 5. Elemental affinities deduced from calculation of Pearson's correlation coefficients between the content of each element in coal samples (not in trunks and glutenite samples) and ash yield or selected elements.

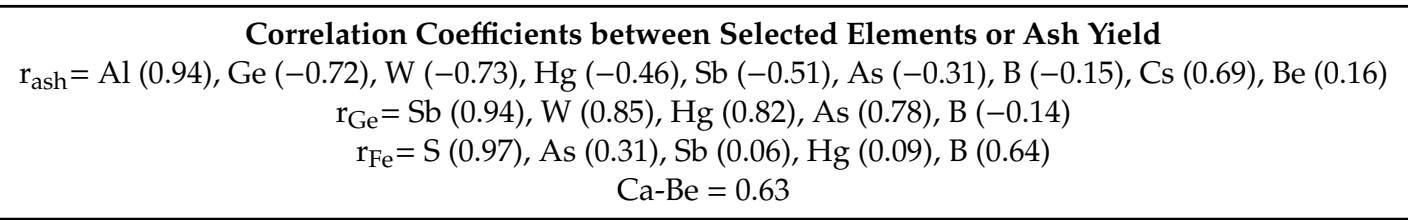

\section{Discussion}

\subsection{Elevated Ge Contents}

According to the isoline of Ge concentration in the Wulantuga Ge ore deposit from Du et al. [10], which is also shown in Figure 3, the average Ge content in the WZ profile from this study should be around $200 \mathrm{mg} / \mathrm{kg}$. The average Ge content from coal bench samples in this study is $197 \mathrm{mg} / \mathrm{kg}$, which is in accordance with the fan-shaped distribution of Ge proposed by Du et al. [10].

There is a large difference between the macerals in the central and outer parts of the coalified trunk due to the high inertinite content in the outer part of the coalified trunk. In contrast, the concentration of Ge is much higher in the central part, indicating that Ge is most likely associated with huminite, which is confirmed by the correlation of Ge-huminite $(r=0.43)$ and Ge-inertinite $(r=-0.45)$. This is also reported in previous studies [33,70]. For example, Etschmann et al. pointed out that Ge in low-rank coals is bound to the organic matrix by means of $O$ functional groups [70], and the carboxylic acid and catechol functional groups as already suggested by Pokrovski et al. [71]. Wei et al. found that inertinite in two selected coal samples from the Wulantuga high-Ge pit mine have lower $\mathrm{O}$ and higher $\mathrm{C}$ compared to huminite, and $\mathrm{Ge}$ in these samples show a preferential enrichment in huminite relative to inertinite [33].

The previous studies have shown that the enriched Ge content in the Wulantuga coals was derived from the high-Ge hydrothermal solution $[8-10,15,18,31-35,37]$. In the present study, the unusually elevated concentrations of Ge are most likely derived from the influx of hydrothermal solutions as attested by (1) the presence of pyrite vein in the fracture of coal seam; (2) elemental associations of $\mathrm{Ge}-\mathrm{W}$ and As-Sb-Hg in coal samples; (3) the appearance of chamosite in studied lignite samples.

\subsection{Elevated B Contents}

Compared to other high-Ge coals in Wulantuga $[9,10,18]$, the high-Ge coal in this study has a higher B content $(94.3 \mathrm{mg} / \mathrm{kg})$. Boron in the Wulantuga Ge-rich coals is considered to have an organic-inorganic mixed affinity $[7,9]$. In this study, the slightly negative correlations of B-ash $(r=-0.15)$ and $B-G e$ 
$(\mathrm{r}=-0.14)$ (Table 5) also indicates an organic-inorganic mixed affinity of B. Further, the relatively high correlation of B-Fe $(r=0.64)$ and the high content of B in the pyrite vein sample $(116 \mathrm{mg} / \mathrm{kg})$ suggest that a portion of $\mathrm{B}$ is possibly associated with pyrite.

According to the previous study, the enriched B in Wulantuga coals were derived from acid water giving rise to elevated concentrations of $\mathrm{B}$ in both the Ge-rich and low-Ge coals in Wulantuga ore deposit [7]. In this study, boron was most likely derived from the Fe-rich solution involved in the pyrite formation, as confirmed by the relatively significant correlation of B-Fe $(r=0.64)$ and higher $B$ content in the pyrite veins.

\subsection{Environmental Impacts of Coalified Trunk}

The coalified trunk contains significantly high contents of potential environmental hazardous elements (As, Sb, Hg, and S) in both the inner and outer parts of it (Table 4). During the fieldwork, the coalified trunks have been wasted and covered by a thin layer of sandstone in unexploited areas (Figure 4), and the coalified trunks once covered the mined coal have been wasted in a gangue dump near the open-pit mine. Previous studies have shown that both weathered coal gangue and burnt or unburnt waste dump from coal mine have potential impacts on the local environment [72,73] and human health [74]. However, the potential environmental impacts of coalified trunks in the Wulantuga Ge-coal deposit have never attracted attention. Although a great portion of pyrite in coalified trunks have been oxidized into Fe sulfates, there is still a certain amount of pyrite presented in coalified trunks (Table 3, Figures 7 and 8). Further, the amount of coalified trunks wasted in the gangue dump is considerable. Thus, the coalified trunks with significantly high contents of potential environmentally hazardous elements in the studying area should be taken into consideration during mining waste disposal and land reclamation.

In addition, the coalified trunk samples are significantly enriched in Ge $(988.7 \mathrm{mg} / \mathrm{kg}$ on average). Considering the large amount of them wasted in the gangue dump and their high concentration of Ge, the coalified trunks may be another source of Ge-extraction in the Wulantuga open-pit mine.

\section{Conclusions}

The high-Ge Wulantuga \#6 coal analyzed in this study is low-ash lignite. The macerals mainly include inertinite (59\% on average) and huminite $(40 \%)$, the former of which is mainly composed of semifusinite, fusinite, and inertodetrinite, and the latter of which is mainly gelinite and textinite. Minerals in coals consist mainly of quartz, kaolinite, pyrite, and montmorillonite, along with a minor amount of gypsum and traces of barite, chlorite, and iron oxides. Minerals present in coalified trunk samples primarily include melanterite, pyrite, gypsum, magnesiocopiapite, $\mathrm{Al}-\mathrm{Fe}-\mathrm{Mg}$ sulfates, iron oxides, quartz, kaolinite, and chlorite.

Compared to the averages of world coals, element Ge (23-492 mg/kg, $197 \mathrm{mg} / \mathrm{kg}$ on average), As (118-476 mg/kg, average 263mg/kg), and W (77-526 mg/kg, average $305 \mathrm{mg} / \mathrm{kg}), \mathrm{Sb}(0.1-24 \mathrm{mg} / \mathrm{kg}$, average $6 \mathrm{mg} / \mathrm{kg})$, and $\mathrm{Hg}(0-2.5 \mathrm{mg} / \mathrm{kg}$, average $0.7 \mathrm{mg} / \mathrm{kg})$ are enriched in the Wulantuga \#6 coal and highly enriched in the coalified trunks and roof glutenite. The elevated content of Ge is most likely associated with huminite and are most likely derived from the influx of hydrothermal solutions as indicated by the presence of pyrite veins and chamosite, as well as enhanced elemental associations of $\mathrm{Ge}-\mathrm{W}$ and $\mathrm{As}-\mathrm{Sb}-\mathrm{Hg}$ in the studied lignite samples. Boron has a relatively higher content than other Ge-rich coals in Wulantuga high-Ge coal deposit and was most likely derived from the Fe-rich solution involved in the formation of pyrite.

Our findings have relevant implications, not only for the genetic patterns of the high Ge-W-As-Sb-Hg geochemical anomaly of the Wulantuga Cretaceous coals, but also for the potential of environmental impacts and Ge-extraction. This should be taken into account during the disposal of mining waste and land reclamation. 
Author Contributions: Conceptualization, C.Y. and X.Z.; Formal analysis, C.Y.; Funding acquisition, X.Z.; Investigation, C.Y., X.Z., J.L., B.L., N.M. and F.Z.; Visualization, C.Y.; Writing-original draft, C.Y.; Writing-review \& editing, C.Y., X.Z. and X.Q. All authors have read and agreed to the published version of the manuscript.

Funding: This research was funded by the Key Program of Ministry of Science and Technology of China (No. 2016YFA0602002), National Science Foundation for Young Scientists of China (No. 41602176), the National Science Foundation of China (No 41972180), and Key Laboratory of Tectonics and Petroleum Resources (TPR-2018-16), as well as was supported by the "Overseas Top Scholars Program", part of the "Recruitment Program of Global Experts" (No. G20190017067). The authors would like to express sincere thanks to the Institute of Environmental Assessment and Water Research, CSIC, Spain for assistance with the sample analysis.

Acknowledgments: The authors would like to express sincere thanks to the Institute of Environmental Assessment and Water Research, CSIC, Spain for assistance with the sample analysis.

Conflicts of Interest: The authors declare no conflict of interest.

\section{References}

1. Dai, S.; Finkelman, R.B. Coal as a promising source of critical elements: Progress and future prospects. Int. J. Coal Geol. 2018, 186, 155-164. [CrossRef]

2. Dai, S.; Graham, I.T.; Ward, C.R. A review of anomalous rare earth elements and yttrium in coal. Int. J. Coal Geol. 2016, 159, 82-95. [CrossRef]

3. Dai, S.; Ren, D.; Chou, C.-L.; Finkelman, R.B.; Seredin, V.V.; Zhou, Y. Geochemistry of trace elements in Chinese coals: A review of abundances, genetic types, impacts on human health, and industrial utilization. Int. J. Coal Geol. 2012, 94, 3-21. [CrossRef]

4. Li, J.; Zhuang, X.; Yuan, W.; Liu, B.; Querol, X.; Font, O.; Moreno, N.; Li, J.; Gang, T.; Liang, G. Mineral composition and geochemical characteristics of the Li-Ga-rich coals in the Buertaohai-Tianjiashipan mining district, Jungar Coalfield, Inner Mongolia. Int. J. Coal Geol. 2016, 167, 157-175. [CrossRef]

5. Seredin, V.V.; Dai, S. Coal deposits as potential alternative sources for lanthanides and yttrium. Int. J. Coal Geol. 2012, 94, 67-93. [CrossRef]

6. Seredin, V.V.; Finkelman, R.B. Metalliferous coals: A review of the main genetic and geochemical types. Int. J. Coal Geol. 2008, 76, 253-289. [CrossRef]

7. Dai, S.; Liu, J.; Ward, C.R.; Hower, J.C.; Xie, P.; Jiang, Y.; Hood, M.M.; O’Keefe, J.M.K.; Song, H. Petrological, geochemical, and mineralogical compositions of the low-Ge coals from the Shengli Coalfield, China: A comparative study with Ge-rich coals and a formation model for coal-hosted Ge ore deposit. Ore Geol. Rev. 2015, 71, 318-349. [CrossRef]

8. Dai, S.; Wang, P.; Ward, C.R.; Tang, Y.; Song, X.; Jiang, J.; Hower, J.C.; Li, T.; Seredin, V.V.; Wagner, N.J.; et al. Elemental and mineralogical anomalies in the coal-hosted Ge ore deposit of Lincang, Yunnan, southwestern China: Key role of $\mathrm{N}_{2}-\mathrm{CO}_{2}$-mixed hydrothermal solutions. Int. J. Coal Geol. 2015, 152, 19-46. [CrossRef]

9. Dai, S.; Wang, X.; Seredin, V.V.; Hower, J.C.; Ward, C.R.; O’Keefe, J.M.K.; Huang, W.; Li, T.; Li, X.; Liu, H.; et al. Petrology, mineralogy, and geochemistry of the Ge-rich coal from the Wulantuga Ge ore deposit, Inner Mongolia, China: New data and genetic implications. Int. J. Coal Geol. 2012, 90-91, 72-99. [CrossRef]

10. Du, G.; Zhuang, X.; Querol, X.; Izquierdo, M.; Alastuey, A.; Moreno, T.; Font, O. Ge distribution in the Wulantuga high-germanium coal deposit in the Shengli coalfield, Inner Mongolia, northeastern China. Int. J. Coal Geol. 2009, 78, 16-26. [CrossRef]

11. Hower, J.C.; Ruppert, L.F.; Williams, D.A. Controls on boron and germanium distribution in the low-sulfur Amos coal bed, Western Kentucky coalfield, USA. Int. J. Coal Geol. 2002, 53, 27-42. [CrossRef]

12. Hu, R.-Z.; Qi, H.-W.; Zhou, M.-F.; Su, W.-C.; Bi, X.-W.; Peng, J.-T.; Zhong, H. Geological and geochemical constraints on the origin of the giant Lincang coal seam-hosted germanium deposit, Yunnan, SW China: A review. Ore Geol. Rev. 2009, 36, 221-234. [CrossRef]

13. Li, J.; Zhuang, X.; Querol, X.; Font, O.; Izquierdo, M.; Wang, Z. New data on mineralogy and geochemistry of high-Ge coals in the Yimin coalfield, Inner Mongolia, China. Int. J. Coal Geol. 2014, 125, 10-21. [CrossRef]

14. Mastalerz, M.; Drobniak, A. Gallium and germanium in selected Indiana coals. Int. J. Coal Geol. 2012, 94, 302-313. [CrossRef]

15. Qi, H.; Hu, R.; Zhang, Q. Concentration and distribution of trace elements in lignite from the Shengli Coalfield, Inner Mongolia, China: Implications on origin of the associated Wulantuga Germanium Deposit. Int. J. Coal Geol. 2007, 71, 129-152. [CrossRef] 
16. Seredin, V.V. Anomalous trace elements contents in the spetsugli germanium deposit (pavlovka brown coal deposit) southern Primorye: Communication 1. Antimony. Lithol. Miner. Resour. 2003, 38, 154-161. [CrossRef]

17. Seredin, V.V. Metalliferous coals: Formation conditions and outlooks for development. Coal Resour. Russ. 2004, 6, 452-519.

18. Zhuang, X.; Querol, X.; Alastuey, A.; Juan, R.; Plana, F.; Lopez-Soler, A.; Du, G.; Martynov, V.V. Geochemistry and mineralogy of the Cretaceous Wulantuga high-germanium coal deposit in Shengli coal field, Inner Mongolia, Northeastern China. Int. J. Coal Geol. 2006, 66, 119-136. [CrossRef]

19. Zilbermints, V.A.; Rusanov, A.K.; Kosrykin, V.M. On the question of Ge-presence in fossil coals. Acad. V.I.Vernadsky-k 1936, 1, 169-190.

20. Hu, R.; Bi, X.; Ye, Z.; Su, W. The genesis of Lincang germanium deposit-A preliminary investigation. Chin. J. Geochem. 1996, 15, 44-50. [CrossRef]

21. Wang, L. Introduction of the geological feature and explorating of wulantuga germanium deposit inXilinguole League, Inner Mongolia. Geol. Inn. Mangolia 1999, 3, 15-20, (In Chinese with English abstract).

22. Seredin, V.V.; Danilcheva, J. Coal-hosted Ge deposits of the Russian far east. In Mineral Deposits at the Beginning of the 21st Century; Swets and Zeitlinger Publishers: Lisse, The Netherlands, 2001; pp. 89-92.

23. Seredin, V.V.; Danilcheva, Y.A.; Magazina, L.O.; Sharova, I.G. Ge-bearing coals of the Luzanovka Graben, Pavlovka brown coal deposit, southern Primorye. Lithol. Miner. Resour. 2006, 41, 280-301. [CrossRef]

24. Wu, W.; Mo, R.; Wang, Z. Occurrence features and geological work of germanium resource in Yimin coal field, Inner Mongolia. Inn. Mong. Geol. 2002, 1, 27-30.

25. Kulinenko, O.R. Relationship between germanium content and seam thickness in Paleozoic paralic coal basins of Ukraine. Int. Geol. Rev. 1977, 19, 1178-1182. [CrossRef]

26. Yudovich, Y.E. Notes on the marginal enrichment of germanium in coal beds. Int. J. Coal Geol. 2003, 56, 223-232. [CrossRef]

27. Hu, R.; Qi, H.; Bi, X.; Su, W.; Peng, J. Geology and geochemistry of the Lincang superlarge Germanium deposit hosted in coal seams, Yunnan, China. Geochim. Cosmochim. Acta Suppl. 2006, 70, A269. [CrossRef]

28. Zhuang, H.; Lu, J.; Fu, J.; Liu, J.; Ren, C.; Zou, D. Germanium occurrence in Lincang superlarge deposit in Yunnan, China. Sci. China Ser. D Earth Sci. 1998, 41, 21-27. [CrossRef]

29. Qi, H.W.; Hu, R.Z. Trace element geochemistry of Lincang germanium deposit. Coal Geol. Explor. 2002, 30, $1-2$.

30. Qi, H.; Hu, R.; Su, W.; Qi, L.; Feng, J. Continental hydrothermal sedimentary siliceous rock and genesis of superlarge germanium (Ge) deposit hosted in coal: A study from the Lincang Ge deposit, Yunnan, China. Sci. China Ser. D Earth Sci. 2004, 47, 973. [CrossRef]

31. Li, J.; Zhuang, X.; Querol, X. Trace element affinities in two high-Ge coals from China. Fuel 2011, 90, $240-247$. [CrossRef]

32. Wei, Q.; Rimmer, S.M. Acid solubility and affinities of trace elements in the high-Ge coals from Wulantuga (Inner Mongolia) and Lincang (Yunnan Province), China. Int. J. Coal Geol. 2017, 178, 39-55. [CrossRef]

33. Wei, Q.; Dai, S.; Lefticariu, L.; Costin, G. Electron probe microanalysis of major and trace elements in coals and their low-temperature ashes from the Wulantuga and Lincang Ge ore deposits, China. Fuel 2018, 215, 1-12. [CrossRef]

34. Du, G.; Tang, D.Z.; Wu, W.; Sun, P.C.; Bai, Y.L.; Yang, W.B.; Xuan, Y.Q.; Zhang, L.C. Research on grade variation regularity of paragenetic germanium deposit along uprightness in Shengli Coalfield, Inner Mongolia. Coal Geol. Explor. 2004, 32, 1-4.

35. Qi, H.; Hu, R.; Zhang, Q. REE Geochemistry of the Cretaceous lignite from Wulantuga Germanium Deposit, Inner Mongolia, Northeastern China. Int. J. Coal Geol. 2007, 71, 329-344. [CrossRef]

36. Dai, S.; Hower, J.C.; Finkelman, R.B.; Graham, I.T.; French, D.; Ward, C.R.; Eskenazy, G.; Wei, Q.; Zhao, L. Organic associations of non-mineral elements in coal: A review. Int. J. Coal Geol. 2019, 218, 103347. [CrossRef]

37. Dai, S.; Seredin, V.V.; Ward, C.R.; Jiang, J.; Hower, J.C.; Song, X.; Jiang, Y.; Wang, X.; Gornostaeva, T.; Li, X.; et al. Composition and modes of occurrence of minerals and elements in coal combustion products derived from high-Ge coals. Int. J. Coal Geol. 2014, 121, 79-97. [CrossRef]

38. Cui, X.; Li, J. The late mesozoic stratigraphy and palaeontologyof the Erlian Basin Group in Inner Mongolia, China. Geosci. J. Graduate Sch. China Univ. Geosci. 1991, 5, 397-408, (In Chinese with English Abstract). 
39. Cui, X.; Li, J. Late Mesozoic basin types and their coal accumulation characteristics of Erlian basins in Inner Mongolia. Geosci. J. Graduate Sch. China Univ. Geosci. 1993, 7, 479-484, (In Chinese with English Abstract).

40. Sha, J. Cretaceous stratigraphy of northeast China: Non-marine and marine correlation. Cretac. Res. 2007, 28, 146-170. [CrossRef]

41. ISO. ISO 589: Hard Coal_Determination of Total Moisture; ISO: Geneva, Switzerland, 2008.

42. ISO. Solid Mineral Fuels—Determination of Ash; ISO: Geneva, Switzerland, 2010.

43. ISO. Hard Coal and Coke—Determination of Volatile Matter; ISO: Geneva, Switzerland, 2010.

44. ICCP. The new vitrinite classification (ICCP System 1994). Fuel 1998, 77, 349-358. [CrossRef]

45. ICCP. The new inertinite classification (ICCP System 1994). Fuel 2001, 80, 459-471. [CrossRef]

46. Pickel, W.; Kus, J.; Flores, D.; Kalaitzidis, S.; Christanis, K.; Cardott, B.; Misz-Kennan, M.; Rodrigues, S.; Hentschel, A.; Hamor-Vido, M. Classification of liptinite-ICCP System 1994. Int. J. Coal Geol. 2017, 169, 40-61. [CrossRef]

47. Chung, F.H. Quantitative interpretation of X-ray diffraction patterns of mixtures. I. Matrix-flushing method for quantitative multicomponent analysis. J. Appl. Crystallogr. 1974, 7, 519-525. [CrossRef]

48. Querol, X.; Whateley, M.; Fernandez-Turiel, J.L.; Tuncali, E. Geological controls on the mineralogy and geochemistry of the Beypazari lignite, central Anatolia, Turkey. Int. J. Coal Geol. 1997, 33, 255-271. [CrossRef]

49. Li, J.; Zhuang, X.; Querol, X.; Font, O.; Moreno, N.; Zhou, J.; Lei, G. High quality of Jurassic Coals in the Southern and Eastern Junggar Coalfields, Xinjiang, NW China: Geochemical and mineralogical characteristics. Int. J. Coal Geol. 2012, 99, 1-15. [CrossRef]

50. National Standard of P.R. China. Classification for Quality of Coal. Moisture Content; Standards Press of China: Beijing, China, 2000. (In Chinese)

51. National Standard of P.R. China. Classification for Quality of Coal. Volatile Yield; Standards Press of China: Beijing, China, 2000. (In Chinese)

52. National Standard of P.R. China. Classification for Quality of Coal. Part 1: Ash Yield; Standards Press of China: Beijing, China, 2010. (In Chinese)

53. Stach, E. Stach's Textbook of Coal Petrology; Gebrüder Borntraeger: Berlin, Germany, 1982.

54. Ward, C.R.; Christie, P.J. Clays and other minerals in coal seams of the Moura-Baralaba area, Bowen Basin, Australia. Int. J. Coal Geol. 1994, 25, 287-309. [CrossRef]

55. Permana, A.K. Mineralogical Variation and Changes in the South Walker Creek Coals, Bowen Basin, Queensland, Australia. Master's Thesis, University of New South Wales, Kensington, Australia, 2011.

56. Permana, A.K.; Ward, C.R.; Li, Z.; Gurba, L.W. Distribution and origin of minerals in high-rank coals of the South Walker Creek area, Bowen Basin, Australia. Int. J. Coal Geol. 2013, 116, 185-207. [CrossRef]

57. Susilawati, R.; Ward, C.R. Metamorphism of mineral matter in coal from the Bukit Asam deposit, south Sumatra, Indonesia. Int. J. Coal Geol. 2006, 68, 171-195. [CrossRef]

58. Vassilev, S.V.; Kitano, K.; Vassileva, C.G. Some relationships between coal rank and chemical and mineral composition. Fuel 1996, 75, 1537-1542. [CrossRef]

59. Sangüesa, F.J.; Arostegui, J.; Suarez-Ruiz, I. Distribution and origin of clay minerals in the Lower Cretaceous of the Alava Block (Basque-Cantabrian Basin, Spain). Clay Miner. 2000, 35, 393-410. [CrossRef]

60. Wang, X.; Zhang, M.; Zhang, W.; Wang, J.; Zhou, Y.; Song, X.; Li, T.; Li, X.; Liu, H.; Zhao, L. Occurrence and origins of minerals in mixed-layer illite/smectite-rich coals of the Late Permian age from the Changxing Mine, eastern Yunnan, China. Int. J. Coal Geol. 2012, 102, 26-34. [CrossRef]

61. Dai, S.; Ren, D.; Tang, Y.; Shao, L.; Li, S. Distribution, isotopic variation and origin of sulfur in coals in the Wuda coalfield, Inner Mongolia, China. Int. J. Coal Geol. 2002, 51, 237-250. [CrossRef]

62. Chou, C.-L. Sulfur in coals: A review of geochemistry and origins. Int. J. Coal Geol. 2012, 100, 1-13. [CrossRef]

63. Rao, C.P.; Gluskoter, H.J. Occurrence and distribution of minerals in Illinois coals. Illinois State Geol. Surv. Circular 1973, 476, 56.

64. Finkelman, R.B.; Dai, S.; French, D. The importance of minerals in coal as the hosts of chemical elements: A review. Int. J. Coal Geol. 2019, 212, 103251. [CrossRef]

65. Ward, C.R. Analysis and significance of mineral matter in coal seams. Int. J. Coal Geol. 2002, 50, $135-168$. [CrossRef]

66. Ward, C.R. Analysis, origin and significance of mineral matter in coal: An updated review. Int. J. Coal Geol. 2016, 165, 1-27. [CrossRef] 
67. Spiro, B.F.; Liu, J.; Dai, S.; Zeng, R.; Large, D.; French, D. Marine derived 87Sr/86Sr in coal, a new key to geochronology and palaeoenvironment: Elucidation of the India-Eurasia and China-Indochina collisions in Yunnan, China. Int. J. Coal Geol. 2019, 215, 103304. [CrossRef]

68. Ketris, M.P.; Yudovich, Y.E. Estimations of Clarkes for Carbonaceous biolithes: World averages for trace element contents in black shales and coals. Int. J. Coal Geol. 2009, 78, 135-148. [CrossRef]

69. Dai, S.; Seredin, V.V.; Ward, C.R.; Hower, J.C.; Xing, Y.; Zhang, W.; Song, W.; Wang, P. Enrichment of U-Se-Mo-Re-V in coals preserved within marine carbonate successions: Geochemical and mineralogical data from the Late Permian Guiding Coalfield, Guizhou, China. Miner. Depos. 2015, 50, 159-186. [CrossRef]

70. Etschmann, B.; Liu, W.; Li, K.; Dai, S.; Reith, F.; Falconer, D.; Kerr, G.; Paterson, D.; Howard, D.; Kappen, P.; et al. Enrichment of germanium and associated arsenic and tungsten in coal and roll-front uranium deposits. Chem. Geol. 2017, 463, 29-49. [CrossRef]

71. Pokrovski, G.S.; Martin, F.; Hazemann, J.-L.; Schott, J. An X-ray absorption fine structure spectroscopy study of germanium-organic ligand complexes in aqueous solution. Chem. Geol. 2000, 163, 151-165. [CrossRef]

72. Kř́bek, B.; Sýkorová, I.; Veselovský, F.; Laufek, F.; Malec, J.; Knésl, I.; Majer, V. Trace element geochemistry of self-burning and weathering of a mineralized coal waste dump: The Novátor mine, Czech Republic. Int. J. Coal Geol. 2017, 173, 158-175. [CrossRef]

73. Querol, X.; Izquierdo, M.; Monfort, E.; Álvarez, E.; Font, O.; Moreno, T.; Alastuey, A.; Zhuang, X.; Lu, W.; Wang, Y. Environmental characterization of burnt coal gangue banks at Yangquan, Shanxi Province, China. Int. J. Coal Geol. 2008, 75, 93-104. [CrossRef]

74. Finkelman, R.B. Potential health impacts of burning coal beds and waste banks. Int. J. Coal Geol. 2004, 59, 19-24. [CrossRef]

(C) 2019 by the authors. Licensee MDPI, Basel, Switzerland. This article is an open access article distributed under the terms and conditions of the Creative Commons Attribution (CC BY) license (http://creativecommons.org/licenses/by/4.0/). 